\title{
Energy fluxes and surface characteristics over a cultivated area in Benin: daily and seasonal dynamics
}

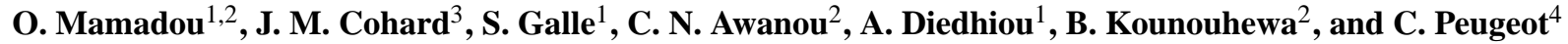 \\ ${ }^{1}$ IRD, LTHE - UMR5564, CNRS/UJF-Grenoble 1/G-INP/IRD, 38041 Grenoble, France \\ ${ }^{2}$ Laboratoire de Physique du Rayonnement, Faculté des Sciences et Techniques, Université d'Abomey-Calavi, \\ Abomey-Calavi, Benin \\ ${ }^{3}$ UJF-Grenoble 1, LTHE - UMR5564, CNRS/UJF-Grenoble 1/G-INP/IRD, 38041 Grenoble, France \\ ${ }^{4}$ IRD, HSM, UMR5569 - CNRS/UM1/UM2, 34095 Montpellier, France
}

Correspondence to: O. Mamadou (ossenatou.mamadou@ujf-grenoble.fr) and J.-M. Cohard (jean-martial.cohard@ujf-grenoble.fr)

Received: 9 July 2013 - Published in Hydrol. Earth Syst. Sci. Discuss.: 16 August 2013

Revised: 17 January 2014 - Accepted: 20 January 2014 - Published: 7 March 2014

\begin{abstract}
Latent and sensible heat surface fluxes are key factors of the western African monsoon dynamics. However, few long-term observations of these land surface fluxes are available; these are needed to increase understanding of the underlying processes and assess their impacts on the energy and water cycles at the surface-atmosphere interface. This study analyzes turbulent fluxes of one full year, measured with the eddy covariance technique, over a cultivated area in northern Benin (western Africa). The study site is part of the long-term AMMA-CATCH (African Monsoon Multidisciplinary Analysis-Coupling of the Tropical Atmosphere and Hydrological Cycle) hydrological observatory. The flux partitioning was investigated through the evaporative fraction $(\mathrm{EF})$ and the Bowen ratio $(\beta)$ at both seasonal and daily scales. Finally, the surface conductance $\left(G_{\mathrm{s}}\right)$ and the decoupling coefficient $(\Omega)$ were calculated and compared with specific bare soil or canopy models.

Four contrasting seasons were identified and characterized by their typical daily energy cycles. The results pointed out the contrasting seasonal variations of sensible and latent heat fluxes due to changing atmospheric and surface conditions. In the dry season, the sensible heat fluxes were largely dominant $(\beta \sim 10)$ and a low but significant evapotranspiration was measured $(\mathrm{EF}=0.08)$; this was attributed to a few neighboring bushes, possibly fed by the water table. During the wet season, after the monsoon onset, surface conditions barely affected the evaporative fraction (EF), which remained steady $(\mathrm{EF}=0.75)$; the latent heat flux was
\end{abstract}

dominant and the Bowen ration $(\beta)$ was about 0.4. During the dry-to-wet and wet-to-dry transition seasons, both EF and $\beta$ were highly variable, as they depended on the atmospheric forcing or the response to isolated rains. A complete surface-atmosphere decoupling was never observed in $2008(0<\Omega<0.6)$, which suggests a systematic mixing of the air within the canopy with the atmospheric surface layer, irrespective of the atmospheric conditions and the vegetation height.

Modeling approaches showed a good agreement of soil resistance with the Sakaguchi bare soil model. Canopy conductance was also well reproduced with the Ball-Berry stomata model. We showed that the skin surface temperature had a large seasonal and daily amplitude, and played a major role in all the surface processes. Consequently, an accurate modeling of the surface temperature is crucial to represent correctly the energy and water budgets for this region.

\section{Introduction}

Since the pioneering work of Charney (1975), numerous studies have confirmed the effects of the continental surface on climate; in particular, they have focused on the major importance of surface-atmosphere exchanges over western Africa (Eltahir, 1998; Koster et al., 2004; Parker et al., 2005; among others). These interactions impact the frequency of the rainy events in the Sahel (Taylor and Lebel, 1998) and 
their location (Taylor et al., 2012). On the seasonal scale, Philippon and Fontaine (2002) suggested that the Guinean rainy season affects the following Sahelian rainy season several weeks later, through a hypothesized continental-scale, water content memory effect, but this is still an open question (Douville et al., 2006). The influence of the vegetation activity on the monsoon dynamics has been evidenced by modeling studies (Xue and Shukla, 1993; Zeng et al., 1999; among others), but very few observations support these results.

In western Africa, the population growth rate $(2.57 \%)$ is one of the most significant in the world (UN, 2011). The population has increased by a factor of four from 1950 to 2010 in this region, and is expected to double by 2050 according to the UN's most highest projection (UN, 2011). This population growth results in a continuous conversion of natural vegetation areas into cultivated area (CSAO, 2012; Judex et al., 2009). In northern Benin (study region), cropland covers $22 \%$ of the landscape area (Judex et al., 2009) and is in continuous expansion. This change in land use may induce a modification of the dynamics of water and energy exchanges between the continental surface and the atmosphere. Consequently, studies based on observation data sets are needed in this region to increase knowledge on the processes driving the partitioning of water and energy at the continental surface, and to estimate the impacts of land cover changes on these surface atmosphere exchanges.

The western African climatic gradient, spreading from the Sahel to the north $(\sim 600 \mathrm{~mm}$ rainfall per year $)$ to the Sudanian zone $(\sim 1200 \mathrm{~mm})$ and the Guinean coast to the south, induces contrasts in the surface energy budget dynamics. Due to this regional contrast, specific studies have to be made on the various subdomains. For the Sahel, a few eddy covariance data sets of surface-atmosphere exchanges are available and their analyses have improved the understanding of the Sahelian surface behavior; these include data sets of savannah dynamics and functioning (Kabat et al., 1997; Monteny et al., 1997), coupled energy and water cycle dynamics (Ramier et al., 2009), and energy partitioning variability and upscaling (Timouk et al., 2009). A few studies made in the Sudanian climate region are also reported in the literature. Mauder et al. (2007) have analyzed eddy covariance data over a fallow bush in Nigeria during a three-week period, focusing on the energy balance closure issues. The first long-term measurements in savanna ecosystems covering periods of more than one year were made by Bagayoko et al. (2007), who analyzed the partitioning of the available energy in turbulent fluxes, and Brümmer et al. (2008), who examined carbon dioxide uptake rates. Lothon et al. (2008) and Lohou et al. (2010) focused on the impact of entrainment on observed turbulent characteristics at the surface. Finally, Schüttemeyer et al. (2006) in Ghana and Guyot et al. (2009, 2012) in Benin have studied the energy partitioning of aggregated fluxes using scintillometry. They showed that the partition of the available energy reached a constant regime during the wet season. Guyot et al. (2009) provided evidence that dry sea- son evapotranspiration was linked to water table discharge; this result was further supported by recent hydrological studies (Descloitres et al., 2011; Séguis et al., 2011; Richard et al., 2013).

None of these studies explicitly related the energy partitioning to the surface characteristics, but all of them emphasized the need for long time series of reference flux data over different land covers, in order to obtain a comprehensive understanding of the functioning of these climatesensitive ecosystems in relation to climate variability. Boone et al. (2009) also pointed out the need for observation data set in order to assess the ability of land surface models to correctly simulate the western African water and energy balance at regional scale.

In the framework of the AMMA campaign (Redelsperger et al., 2006), the AMMA-CATCH (African Monsoon Multidisciplinary Analysis-Coupling of the Tropical Atmosphere and Hydrological Cycle) an observation system was designed to document the long-term impacts of climate and environmental changes on the hydrological cycle. It provided a consistent set of meteorological (including surface fluxes), hydrological, and biophysical data sets, covering various vegetation types over contrasting sites, ranging from 9.5 to $17^{\circ} \mathrm{N}$ in latitude (Lebel et al., 2009).

This study focuses on the analysis of a full year of eddy covariance surface flux measurements, collected for a cultivated area on the southern AMMA-CATCH site, located in the Sudanian climate region in northern Benin (Fig. 1). The objectives of this paper are threefold: (1) to document the seasonal and daily variations of latent (LE) and sensible $(H)$ heat fluxes over a crop field in this Sudanian region; (2) to analyze and quantify the energy partitioning as a function of surface characteristics at the seasonal and daily timescales; (3) to evaluate the ability of standard parameterizations to reproduce the daily and seasonal dynamics of the evapotranspiration in this specific tropical site, as these parameterizations are implemented in land surface models.

\section{Material and methods}

\subsection{Study area}

The Nalohou site is located in northern Benin (Fig. 1). In this region, the rainfall regime is driven by the seasonal migration of the intertropical convergence zone (ITCZ), with $90 \%$ of the annual rainfall falling in seven months (April to October), and a mean rainfall amount of $1190 \mathrm{~mm}$ (1950-2002) (Lelay and Galle, 2005).

The landscape is rather flat, with a local slope of about $3 \%$, overlying a metamorphic crystalline bedrock. The main soils are ferric lixisols (Faure and Volkoff, 1998). The textural properties of the surface soil layer correspond to loamy sand with high permeability, whereas the underlying 


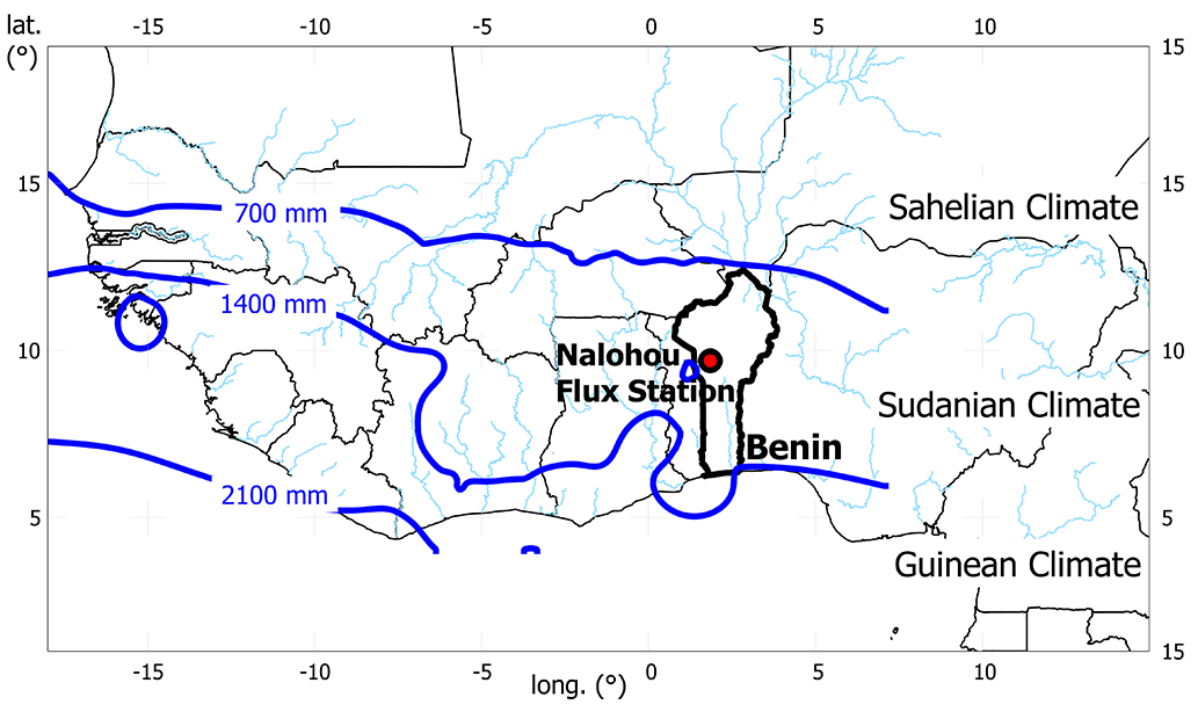

Fig. 1. Localization of the study area in western Africa. Blue lines are the 700, 1400 and 2100 mm isohyets computed from ground observations between 1950 and 2010. They define the different western African climate areas: Sahelian, Sudanian and Guinean climates.

weathered bedrock contains deep clayey layers with high retention properties (De Condappa et al., 2008).

The flux tower was installed near the Nalohou village (lat. $9.74^{\circ} \mathrm{N}$, long. $1.60^{\circ} \mathrm{E}, 449 \mathrm{~m}$ a.s.l). It is located in a cultivated area which consists of crops alternating with fallows. The flux tower has been installed in an herbaceous fallow parcel, surrounded by small fields $(<1$ ha) with a large variety of rain-fed annual crops (cassava, yam, maize, and groundnut, Fig. 4). Crop rotation is the main farming practice in the area. Fallow areas are commonly covered by scattered shrubs, overlaid by a dense herbaceous layer during the wet season. The herbaceous layer usually starts growing in April after the first rains and reaches its maximum height (up to $2.5 \mathrm{~m}$ ) in October. Controlled fire is a traditional practice in Benin; the vegetation (mainly the herbaceous layer) is burnt between November and February, when the soil and vegetation are dry. Hence, during the dry season, the soil is bare for about five months. Isolated trees (with height $<10 \mathrm{~m}$ ), frequently encountered in fields and fallows (agroforestry context), are present in the neighborhood of the flux tower. Such a mixed fallow-field landscape with sparse trees is typical of the northern Benin region.

The water table depth at the tower site is close to the surface and varies, on average, between $1.5 \mathrm{~m}$ in September and $3 \mathrm{~m}$ in June (L. Séguis, personal communication, 2012). The Ara stream, bordered by a riparian forest, flows $250 \mathrm{~m}$ north from the tower. A so-called "bas-fond" (seasonally clogged headwater area, Séguis et al., 2011) is located $70 \mathrm{~m}$ westward. For westerly winds, this area can be included in the flux tower footprint, and thus, it can contribute to the fluxes measured at the tower site. Although this is not the main wind direction, this situation has to be considered to interpret some flux measurements.

\subsection{Instrumentation and data processing}

The meteorological variables (wind speed and direction, air temperature and humidity, and the four components of surface radiative budget) were measured at a $2 \mathrm{~m}$ height; the rainfall was measured with a tipping-bucket rain gauge. The ground measurements included soil temperature $(-10,-20$, and $-40 \mathrm{~cm}$ ) and average soil moisture between 5 and $30 \mathrm{~cm}$. All the measurements were recorded at a $30 \mathrm{~min}$ time step. The sensor characteristics are reported in Table 1. The vegetation height was monitored at a 10-day time step under the flux tower and at 10 locations in its surrounding area. The leaf area index (LAI) time series is a combination of satellite LAI products (CYCLOPE, MODIS, SEVIRI), constrained by in situ measurements derived from hemispherical photographs based on the method proposed by Weiss et al. (2004).

The eddy covariance system used in this study consisted in a fast-response three-dimensional sonic anemometer (CSAT3, Campbell Sci., Logan (UT), USA) and a fastresponse open-path infrared gas analyzer (LI-7500, LI-COR, Lincoln (NE), USA). They were installed at $4.95 \mathrm{~m}$ above the ground, and measured 3-D wind speed, temperature, water vapor and $\mathrm{CO}_{2}$ concentration at a $20 \mathrm{~Hz}$ sampling rate (Table 1).

Half-hourly averages of sensible $(H)$ and latent heat (LE) fluxes were calculated according to theoretical Eqs. (1) and (2) using the CarboEurope protocol (Aubinet et al., 1999), where $\rho$ is the air density $\left(\mathrm{kg} \mathrm{m}^{-3}\right), C_{\mathrm{p}}$ the heat capacity at constant pressure $\left(\mathrm{J} \mathrm{kg}^{-1} \mathrm{~K}^{-1}\right), \lambda$ the latent heat of vaporization $\left(\mathrm{J} \mathrm{g}^{-1}\right), T^{\prime}$ the air temperature fluctuation $(\mathrm{K}), q^{\prime}$ the absolute humidity fluctuation $\left(\mathrm{g} \mathrm{m}^{-3}\right)$, and $w^{\prime}$ the vertical wind speed fluctuation $\left(\mathrm{m} \mathrm{s}^{-1}\right)$. 
Table 1. Instrumentation of Nalohou site. All the measurements were recorded at a 30 min time step.

\begin{tabular}{|c|c|c|c|c|}
\hline Parameter (unit) & Sensor & $\begin{array}{r}\text { Height } \\
\text { a.g.l. }\end{array}$ & Accuracy & $\begin{array}{l}\text { Sampling } \\
\text { rate }\end{array}$ \\
\hline Air temperature $\left({ }^{\circ} \mathrm{C}\right)$ & $\begin{array}{l}\text { Vaisala WXT510 } \\
\text { Capacitive ceramic }\end{array}$ & $2 \mathrm{~m}$ & $\pm 3 \%$ & $10 \mathrm{~s}$ \\
\hline Relative humidity (\%) & $\begin{array}{l}\text { Vaisala WXT510 } \\
\text { Capacitive thin film polymer }\end{array}$ & $2 \mathrm{~m}$ & $\begin{array}{l} \pm 3 \%[0-90 \%] \\
\pm 5 \%[90-100 \%]\end{array}$ & $10 \mathrm{~s}$ \\
\hline $\begin{array}{l}\text { Wind speed }\left(\mathrm{m} \mathrm{s}^{-1}\right) \text { and } \\
\text { direction }\left({ }^{\circ}\right)\end{array}$ & $\begin{array}{l}\text { Vaisala WXT510 } \\
\text { Ultrasonic anemometer }\end{array}$ & $2 \mathrm{~m}$ & $\begin{array}{l} \pm 0.3 \mathrm{~ms}^{-1} \\
\pm 3^{\circ}\end{array}$ & $10 \mathrm{~s}$ \\
\hline $\begin{array}{l}\text { Short wave radiation incoming } \\
\text { and outgoing }\left(\mathrm{W} \mathrm{m}^{-2}\right)\end{array}$ & $\begin{array}{l}\text { Kipp and Zonen CNR1 } \\
\text { Pyranometer } \\
0.305<\lambda<2.8 \mu \mathrm{m}\end{array}$ & $2 \mathrm{~m}$ & $\begin{array}{l} \pm 10 \% \text { for daily } \\
\text { sums }\end{array}$ & $10 \mathrm{~s}$ \\
\hline $\begin{array}{l}\text { Long wave radiation incoming } \\
\text { and outgoing }\left(\mathrm{W} \mathrm{m}^{-2}\right)\end{array}$ & $\begin{array}{l}\text { Kipp and Zonen CNR1 } \\
\text { Pyrgeometer } \\
5<\lambda<50 \mu \mathrm{m}\end{array}$ & $2 \mathrm{~m}$ & $\begin{array}{l} \pm 10 \% \text { for daily } \\
\text { sums }\end{array}$ & $10 \mathrm{~s}$ \\
\hline Rainfall (mm) & $\begin{array}{l}\text { Précis Mécanique ABS3030 } \\
\text { Tipping-bucket rain gauge }\end{array}$ & $1.2 \mathrm{~m}$ & $0.5 \mathrm{~mm}$ & pulse \\
\hline Soil temperature $\left({ }^{\circ} \mathrm{C}\right)$ & $\begin{array}{l}\text { Campbell Sci. T107 } \\
\text { Thermistor }\end{array}$ & $\begin{array}{l}-0.1 \mathrm{~m} \\
-0.2 \mathrm{~m} \\
-0.4 \mathrm{~m}\end{array}$ & $< \pm 0.2^{\circ} \mathrm{C}$ & $10 \mathrm{~s}$ \\
\hline $\begin{array}{l}\text { Volumetric soil moisture } \\
\left(\mathrm{cm}^{3} \mathrm{~cm}^{-3}\right)\end{array}$ & $\begin{array}{l}\text { Campbell Sci. CS616 } \\
\text { Water content reflectometer }\end{array}$ & $\begin{array}{l}-0.1 \mathrm{~m} \\
-0.2 \mathrm{~m}\end{array}$ & $\pm 2.5 \%$ & $10 \mathrm{~s}$ \\
\hline Sensible heat flux $\left(\mathrm{W} \mathrm{m}^{-2}\right)$ & $\begin{array}{l}\text { Campbell Sci. CSAT3 } \\
\text { 3-D sonic anemometer }\end{array}$ & $4.95 \mathrm{~m}$ & $\begin{array}{l}< \pm 4.0 \mathrm{~cm} \mathrm{~s}^{-1}(u, v) \\
< \pm 2.0 \mathrm{~cm} \mathrm{~s}^{-1}(w)\end{array}$ & $20 \mathrm{~Hz}$ \\
\hline Latent heat flux $\left(\mathrm{W} \mathrm{m}^{-2}\right)$ & $\begin{array}{l}\text { LI-7500 } \\
\text { Open-path gas analyzer }\end{array}$ & $4.95 \mathrm{~m}$ & $0.0047 \mathrm{ppt} \mathrm{H}_{2} \mathrm{O}$ & $20 \mathrm{~Hz}$ \\
\hline
\end{tabular}

$H=\rho C_{\mathrm{p}} \overline{w^{\prime} T^{\prime}}$

$\mathrm{LE}=\lambda \overline{w^{\prime} q^{\prime}}$

The data were processed with the EdiRe software (version 1.5.0.28, University of Edinburgh). The procedure included despiking and a double rotation of 3-D wind speed to nullify the vertical wind velocity (Kaimal and Finnigan, 1994; Aubinet et al., 1999). Sonic air temperature was corrected for changes in air humidity and pressure (Schotanus et al., 1983) and for variations in air density due to water vapor (Webb et al., 1980). Time lag corrections were applied to account for time delay between air samples from the sonic anemometer and the gas analyzer. Finally, corrections for frequency response were made in order to account for flux underestimation due to instrument separation and the scale filtering of each sensor (Moore, 1986).

The records corresponding to rainy events and to the $30 \mathrm{~min}$ following the end of the rain were excluded from the analyses to avoid artifacts due to the high sensitivity of the hygrometer to raindrop extinction (Culf et al., 2004). Finally, the records were filtered using the nonstationarity criteria suggested by Mauder and Foken (2004). These tests filtered out the periods in which the flux magnitude or the wind direction varied too much within the 30 min averaging time-step.

The data sets were analyzed on seasonal and daily timescales. Daily averages were computed to characterize the seasonal cycle. Meteorological variables were averaged over the 00:00-24:00 UTC period, whereas surface characteristics, such as evaporative fraction, Bowen ratio and surface conductance, were averaged between 10:00 and 14:00 UTC each day.

The analysis of daily cycles focused on four 15-day periods (named P1 to P4) for which composite daily cycles were computed. These four periods were selected for their quasi-steady-state thermodynamic conditions, and the quasi absence of rain (except during the wet season), to ensure a good quality of the eddy covariance data. These periods have the same number of days, which make their statistical characteristics as comparable as possible. The data screening and filtering procedures described previously eliminated the following: $4 \%$ of $\mathrm{H}$ and $5 \%$ of LE in P1, $20 \%$ of $H$ and $37 \%$ of LE in P2, $35 \%$ of $H$ and $55 \%$ of LE in P3, and $25 \%$ of $H$ and $30 \%$ of LE in P4. 


\subsection{Diagnostic tools for data quality control}

\subsubsection{Footprint analysis}

The definition of the area that contributed to the measured fluxes (the so-called "footprint" area) was an important step in characterizing the representativeness of the measured fluxes. The flux footprint may be defined as "the contribution, per unit emission, of each element of a surface area source to the vertical scalar flux measured at a given height" (Horst and Weil, 1992). Among numerous footprint approaches developed in the past decades (Horst and Weil, 1992; Hsieh et al., 1997, 2000; Schmid, 2002; Kljun et al., 2004), the simple analytical Hsieh 1-D model (Hsieh et al., 2000) with a 2-D extension (Detto et al., 2006) was chosen because of its explicit formulation of a 2-D diffusive footprint calculation. The footprint model was applied to the half-hourly flux data to obtain a succession of 2-D distribution functions of the area contributing to the sensible heat flux. In this study, in order to take into account the strength of the source, we calculated time average footprints, weighting each $30 \mathrm{~min}$ footprint by the corresponding sensible heat flux.

With this definition, the average footprint area mainly represents daytime periods, as nighttime sensible heat fluxes are low. This approach gives a good extension of the average footprint area for water flux sources, but is not representative of $\mathrm{CO}_{2}$ fluxes for which night contributions are as important as day contributions. The roughness length $\left(z_{0}\right)$ and the displacement height $(d)$ used to compute the footprint extension have been derived from the vegetation height using the Brutsaert formulation $\left(d=0.67 \cdot h_{\mathrm{veg}}\right)$. The linear relationship between the roughness length and the vegetation height was inferred from local eddy covariance data $\left(z_{0}=0.17+0.097 \cdot h_{\mathrm{veg}}\right)$. The high residual roughness $(0.17)$ results from the remaining roughness during the dry season (yam bumps and sparse bushes).

\subsubsection{Energy balance}

The energy balance closure is an independent and efficient diagnosis to check the consistency of scalar fluxes measured by an eddy covariance system (Aubinet et al., 1999). According to the surface energy budget, Eq. (3) compares the available energy $\left(R_{\mathrm{n}}-G\right)$ with the sum of turbulent fluxes.

$R_{\mathrm{n}}-G=H+\mathrm{LE}$

$R_{\mathrm{n}}$ is the net radiation $\left(\mathrm{W} \mathrm{m}^{-2}\right)$, and $G$ the ground heat flux $\left(\mathrm{W} \mathrm{m}^{-2}\right)$. The net radiation was calculated from measured incoming and outgoing short- and longwave radiations. The soil heat flux was estimated from soil temperature and moisture profiles using the harmonic method (Guyot et al., 2009), which is based on the estimation of the heat diffusion coefficient from the soil temperature at two depths. The thermal conductivity was computed using the measured soil moisture and the volumetric heat capacity of soil and water.

\subsection{Diagnostic tools to characterize surface processes}

\subsubsection{Derivation of surface parameters}

The surface conductance, $G_{\mathrm{s}},\left(\mathrm{m} \mathrm{s}^{-1}\right)$ quantifies the ability of the soil or the canopy to transfer water to the atmosphere. It was calculated from flux measurements using the Penman-Monteith inverted relationship (Eq. 4), where $G_{\text {a }}$ $\left(\mathrm{m} \mathrm{s}^{-1}\right)$ is the aerodynamic conductance, computed according to Eq. (5), $\Delta\left(\mathrm{Pa} \mathrm{K}^{-1}\right)$ is the slope of the saturation curve, $\gamma\left(\mathrm{Pa} \mathrm{K}^{-1}\right)$ is the psychrometric constant, VPD $(\mathrm{Pa})$ is the vapor pressure deficit, and $\beta=H / \mathrm{LE}$ is the Bowen ratio, defined as the ratio of the sensible to the latent heat flux.

$$
\begin{aligned}
G_{\mathrm{s}} & =\left[\frac{1}{G_{\mathrm{a}}}\left(\frac{\Delta}{\gamma} \beta-1\right)+\frac{\rho C_{\mathrm{p}} \mathrm{VPD}}{\gamma\left(R_{\mathrm{n}}-G\right)}(\beta+1)\right]^{-1} \\
G_{\mathrm{a}} & =\frac{u_{*}^{2}}{u} \frac{\varphi_{H}}{\varphi_{m}}
\end{aligned}
$$

In Eq. (5), $u_{*}$ is the friction velocity, $\varphi_{m}$ and $\varphi_{H}$ are the Businger-Dyer stability functions (Businger et al., 1971). Following Jarvis and McNaughton (1986), the decoupling coefficient $\Omega$ was calculated with Eq. (6). This coefficient varies between 0 , when the vapor deficit in the vicinity of the surface equals the vapor deficit in the atmosphere (coupling conditions), and 1 , when the vapor deficit near the surface is imposed by the surface itself (decoupling conditions).

$$
\Omega=\frac{\Delta / \gamma+1}{\Delta / \gamma+1+G_{\mathrm{a}} / G_{\mathrm{s}}}
$$

Finally, the evaporative fraction, EF, which represents the fraction of the available energy that is converted into evapotranspiration, was calculated with (Eq. 7).

$\mathrm{EF}=\frac{\mathrm{LE}}{H+\mathrm{LE}}$

All these diagnostic variables were computed at a half-hourly time step and were used to build composite diurnal cycles. Midday averages (10:00-14:00 UTC) were also computed to analyze the annual cycle.

\subsubsection{Surface conductance models}

The observed conductance is the combination of aerodynamic, soil, stomata and roots conductance. To analyze these respective contributions to the observed evapotranspiration dynamics in this specific tropical site, different conductance models were considered, for evaporation as well as for transpiration. During the dry and dry-to-wet seasons, when the soil is entirely bare, the bare soil resistance models proposed by Sellers et al. (1992), Lee and Pielke (1992), and Sakaguchi and Zeng (2009) were used to evaluate the ability of these models to capture the behavior of bare soil conductance in tropical conditions. During the wet season, the transpiration processes were modeled with the Ball-Berry stomata 


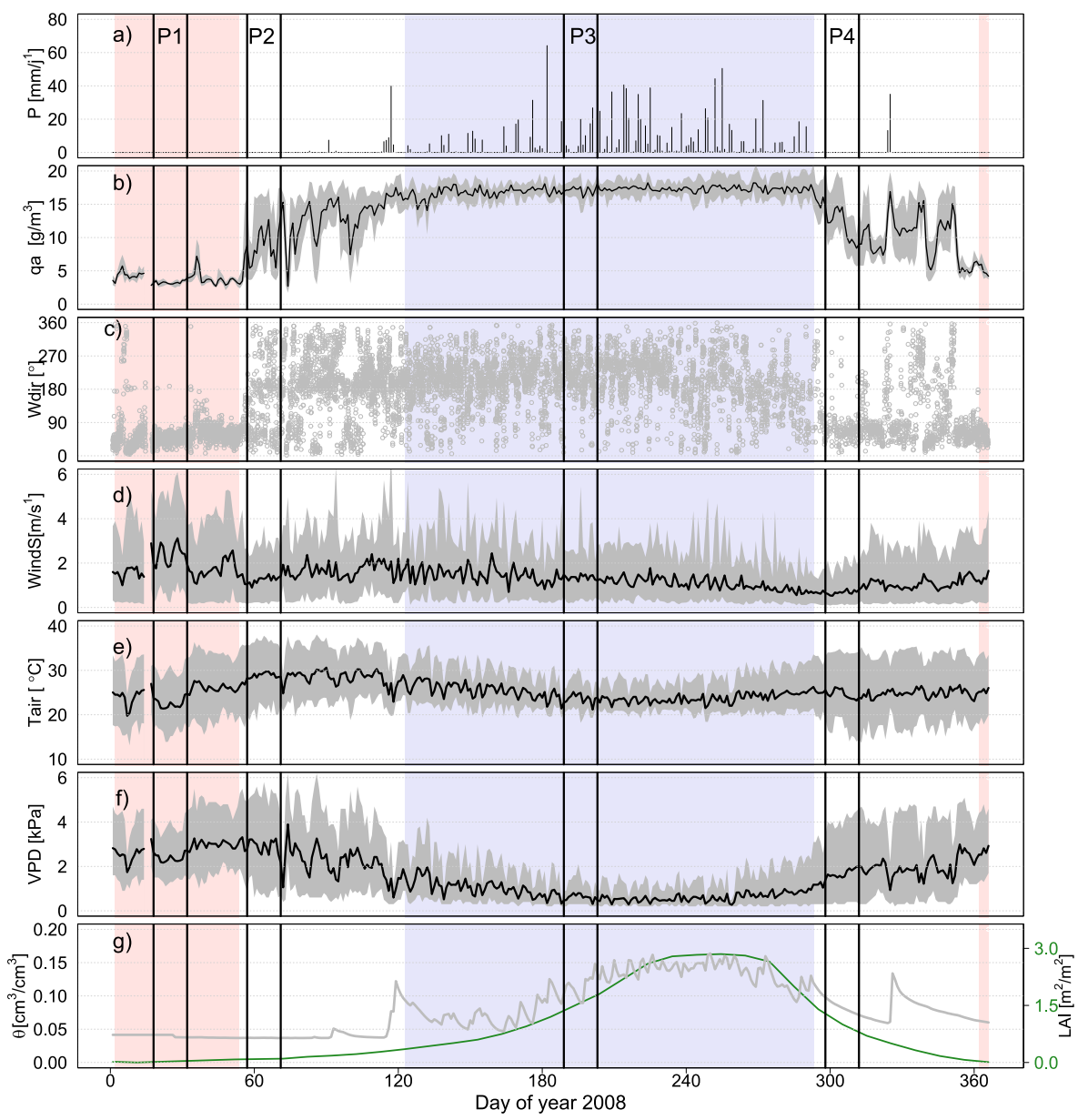

Fig. 2. Seasonal variation of meteorological variables: daily average (black line) and daily range (grey shaded areas) of (a) precipitation, (b) absolute humidity, (c) 30 min instantaneous wind direction, (d) wind speed, (e) air temperature, (f) vapor pressure deficit (VPD), (g) soil water content in the 0-30 cm layer (left axis) and Leaf Area Index (LAI) (right axis). The rose and blue shaded areas highlight the dry and wet season, respectively, according to the absolute humidity $\left(q_{\mathrm{a}}\right)$ criterion (see text). The vertical bars delimit the four studied periods.

conductance model, as described by Collatz et al. (1992) for $\mathrm{C} 4$ vegetation. More details about this model can be found in chapter 8 of the CLM4 technical note (Thornton, 2010). A C4 grass was chosen for stomata characteristics. The required atmospheric (air temperature, precipitation, humidity) and surface (LAI, soil moisture) forcings are those presented further in Fig. 2. The photosynthetically active radiation (PAR) was calculated as a fraction (0.5) of the observed incoming shortwave radiation for both sunlit and shaded leaves. The leaf temperature was assessed from the outgoing longwave radiation measurements using the Stefan-Boltzmann law and a 0.97 emissivity for leaves.

\section{Results and discussion}

\subsection{A contrasting seasonal cycle}

Figures 2 and 3 illustrate the 2008 annual cycle of the atmospheric forcing, the surface conditions and the components of surface the radiative budget. These figures show a succession of wet and dry seasons separated by two dry-to-wet and wet-to-dry transition periods, typical of this Sudanian climate. These four seasons, driven by the monsoon cycle, are characterized by highly contrasting atmospheric and surface conditions which lead to contrasting dynamics of the sensible and latent heat fluxes. Different authors (Sultan and Janicot, 2003; Lothon et al., 2008) have shown that the zonal wind and the water vapor mixing ratio (WVMR) can be used to define the seasons. In this study, the absolute humidity $\left(q_{\mathrm{a}}\right)$ was preferred to WVMR to delimit the seasons because it was directly measured by the gas analyzer; we verified that this criterion did not change drastically the delimitation as 


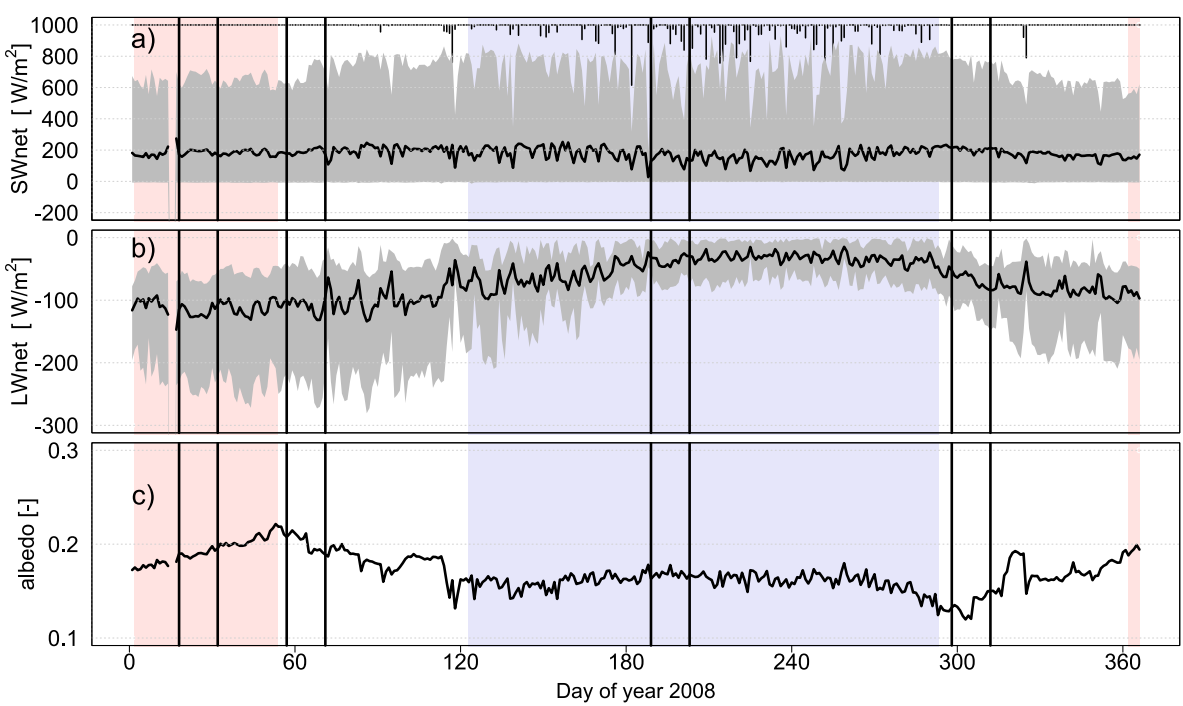

Fig. 3. Seasonal variation of radiation: daily average (black line) and daily range (grey shaded areas) of (a) the net shortwave radiation (SWnet), (b) the net longwave radiation (LWnet) and (c) the surface albedo. The rose and blue shaded areas highlight the dry and wet seasons, respectively. The vertical bars indicate the four studied periods (same as Fig. 2).

compared to the previous methods. The dry $\left(q_{\mathrm{a}}<6 \mathrm{~g} \mathrm{~m}^{-3}\right)$ and wet $\left(q_{\mathrm{a}}>16 \mathrm{~g} \mathrm{~m}^{-3}\right)$ seasons are represented by rose and blue shaded areas, respectively, in Figs. 2, 3, 6 and 10. The four seasons are described in the next section together with four 15-day periods that were chosen to characterize the atmospheric conditions and the surface response characteristics prevailing during each of these stages of the monsoon cycle. In this study, we focused on the net longwave and shortwave radiations, but more details on the four components of the radiative budget can be found in Kounouhéwa et al. (2013).

\subsubsection{Dry season and period 1}

The dry season (rose area in Fig. 2) was characterized by a steady, low $q_{\mathrm{a}}$ and dry north-easterly Harmattan wind that consisted of a light to moderate breeze (mean $2.4 \mathrm{~m} \mathrm{~s}^{-1}$ ), bringing dry air $\left(q_{\mathrm{a}}<5 \mathrm{~g} \mathrm{~m}^{-3}\right.$; VPD $\left.\sim 2.3 \mathrm{kPa}\right)$. The surface conditions were dry and the soils remained bare as no rain occurred. The water content in the $30 \mathrm{~cm}$ top layer was $\sim 0.04 \mathrm{~cm}^{3} \mathrm{~cm}^{-3}$ (Fig. $2 \mathrm{~g}$ ). In the Sudanian climate region, these steady dry conditions usually last less than two months (January-February, Fig. 2).

During the first 15-day period (P1) from DOY 18 to 32 (18 January to 1 February), typical of the dry season, the daily mean air temperature was $23^{\circ} \mathrm{C}$ (Fig. 2e, Table 2). The net shortwave radiation ( $\mathrm{SW}_{\text {net }}$, Fig. 3a) was low (maxima at $\sim 666 \mathrm{~W} \mathrm{~m}^{-2}$ ) - firstly because the aerosols brought by the Harmattan wind reduced the incoming shortwave radiation, and secondly because the dry bare soil conditions induced a high surface albedo $(\sim 0.19$, Fig. $3 c)$. The longwave radiative budget $\left(\mathrm{LW}_{\text {net }}\right)$ was negative all year long (Table 2$)$, corresponding to an energy loss. During period P1, these strong energy losses were associated with low atmospheric water contents and high surface temperatures (Fig. $2 b$ and e). The minimum, maximum and mean $\mathrm{LW}_{\text {net }}$ values were, respectively, $-235,-65 \mathrm{~W} \mathrm{~m}^{-2}$, and $-118 \mathrm{~W} \mathrm{~m}^{-2}$. The sum of short and longwave radiative budgets resulted in low net radiation values.

\subsubsection{Dry to wet season and period 2}

The "moistening transition season" (from dry to wet season) was characterized by monsoon flux intrusions. Southwesterly winds brought moist air from the ocean at night, whereas north-easterly conditions prevailed during the day as shown in (Fig. 2c) where the wind direction abruptly alternated from north to south during the daily cycle. The nighttime advection of moist air (content as high as $18 \mathrm{~g} \mathrm{~m}^{-3}$ ) in the lowest levels of the atmosphere by south-westerly winds is one of the atmospheric signatures of the moistening season. These wet layers were mixed with the whole boundary layer during the following day, when the convection developed and the dry, north-easterly conditions prevailed (Lothon et al., 2008). These peculiar dynamical conditions are due to the large-scale daily ITCZ oscillations and the vertical development of the boundary layer (Pospichal et al., 2010; Lohou et al., 2010). This leads to a gradual, although irregular, increase of the absolute humidity, responsible for the observed day-to-day variability (Fig. 2b). During this period, a few isolated but heavy rainfalls were observed, triggering the development of the vegetation.

The second 15-day period (P2), from DOY 57 to 71 (26 February to 11 March), has been defined as typical of the moistening season. The P2 period captured the whole dry-to-wet air humidity $\left(q_{\mathrm{a}}\right)$ variability, since its daily mean 


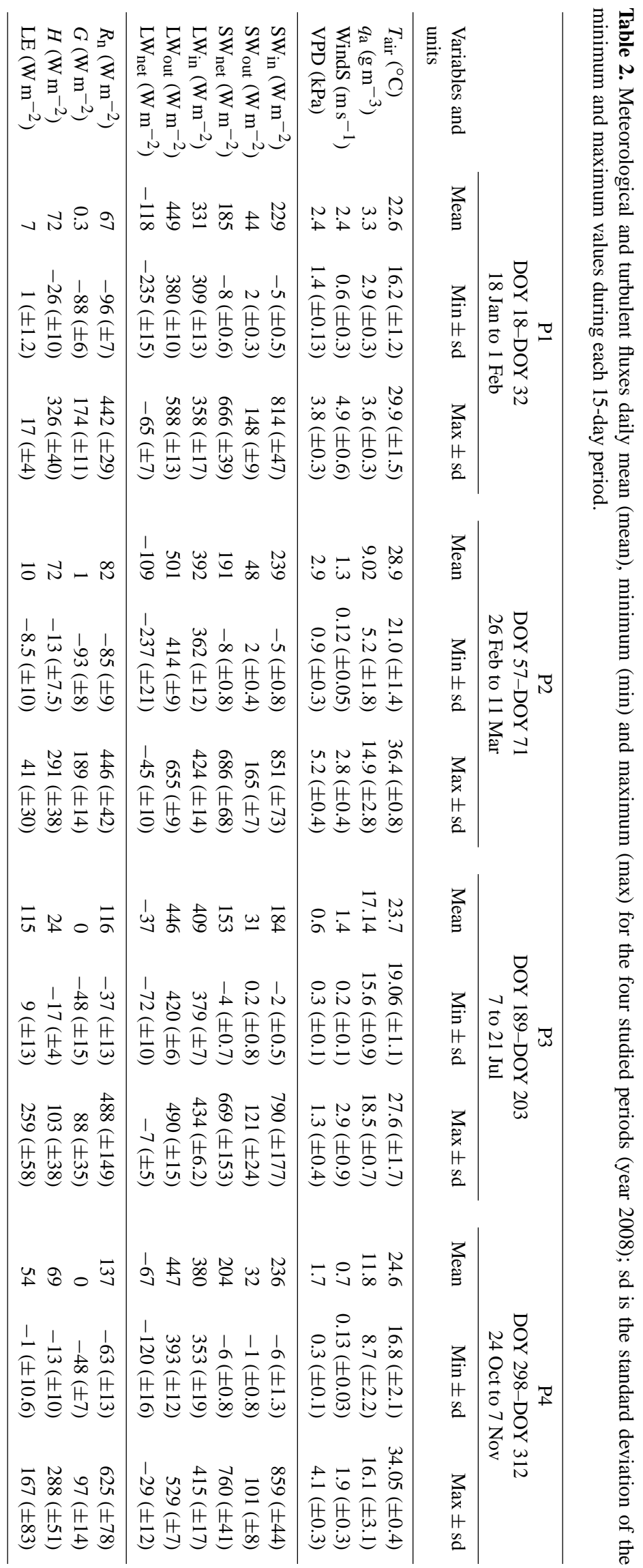


oscillates between 5 and $15 \mathrm{~g} \mathrm{~m}^{-3}$ (Fig. 2b). The surface and radiative conditions were similar to those of period $\mathrm{P} 1$; the surface was still bare and dry, with albedo values close to 0.2 (Fig. 3c), and the maximum value of the net shortwave radiation was only slightly higher than that observed in P1. $\mathrm{LW}_{\text {net }}$ remained strongly negative, even though it increased in comparison to P1, meaning that the surface was still warm at this period of the year (Fig. 3b).

\subsubsection{Wet season and period 3}

The wet season was characterized by a moist, southerly, monsoon flow. The wind direction was well established to be at $240^{\circ}$. According to the definition proposed by Sultan and Janicot (2003), the monsoon onset occurred on 22 June 2008. Rainfall frequency increased after the onset because of a higher occurrence of mesoscale convective events. During this season, the absolute humidity was remarkably stable $\left(\sim 18 \mathrm{~g} \mathrm{~m}^{-3}\right)$ with a low day-to-day variability (Fig. $\left.2 b\right)$. The wet season ended when northerly wind conditions returned.

The P3 period, from DOY 189 to 203 (7 to 21 July), was chosen to be after the monsoon onset. Nine rainy days were observed during this 15-day period, in which $97 \mathrm{~mm}$ of rainfall accumulated. The high soil water content $\left(\sim 0.12 \mathrm{~cm}^{3} \mathrm{~cm}^{-3}\right.$, Fig. $\left.2 \mathrm{~g}\right)$ favored the development of the herbaceous layer (LAI $\sim 1.5 \mathrm{~m}^{2} \mathrm{~m}^{-2}$, Fig. $2 \mathrm{~g}$ ). The net shortwave radiation shows a strong day-to-day variability (Fig. 3a). These variations were related to changes in cloud cover, which reduced the incoming shortwave radiation. Because of the vegetation cover and the wet state of the surface, the albedo reached values lower than in the dry season $(\sim 0.15$, Fig. $3 c)$ and the outgoing shortwave radiation was reduced. In turn, the surface cooling reduced the outgoing longwave radiation and thus increased the net longwave radiation, which reached its highest mean daily value $\left(-37 \mathrm{~W} \mathrm{~m}^{-2}\right.$, Fig. 3b, Table 2). During period P3, the range of variation of the daily air temperature was lower than $10^{\circ} \mathrm{C}$, with a daily mean of about $24^{\circ} \mathrm{C}$. These wet conditions corresponded to a low atmospheric demand (the mean daily VPD was $0.6 \mathrm{kPa}$, Fig. 2f).

\subsubsection{Wet to dry season and period 4}

At the end of the rainy season, when almost no rain occurred, the crops were harvested and the remaining senescent annual vegetation was burnt mid-November. The soil surface began to dry but was not completely dried out (Fig. 2g). The wind direction changed $\left(\sim 70^{\circ}\right)$ but south-westerly conditions were observed from time to time; these brought moisture and sometimes rainfall.

The P4 period, from DOY 298 to 312 (24 October to 7 November) was chosen to be 7 days after the last rainy event of the wet season. The mean air temperature was close to that of the wet season $\left(25^{\circ} \mathrm{C}\right.$, Table 2$)$, but the daily range was larger $\left(17^{\circ} \mathrm{C}\right)$. In this period, the vegetation height was at its yearly maximum, but the senescence phase had begun, as shown by the decrease in LAI (Fig. $2 \mathrm{~g}$ ). Thus, the albedo reached its lowest yearly value $(\sim 0.13$, Fig. $3 \mathrm{c})$. The net shortwave radiation increased (mean daily maximum of $760 \mathrm{~W} \mathrm{~m}^{-2}$ ) for two reasons: albedo decrease and clear-sky conditions (Fig. 3a). The net longwave radiation increased slightly (daily mean of $-67 \mathrm{~W} \mathrm{~m}^{-2}$ ), as the surface dried and the surface temperature increased.

\subsection{Data quality control}

\subsubsection{Spatial representativeness of the eddy covariance measurements}

In the study area, the landscape is composed of small fields interspersed with areas of natural vegetation. For such a context, a footprint analysis is necessary to characterize the representativeness of the measurements. Figure 4 presents the average footprint (as defined in Sect. 2.3.1) for each selected period, superimposed on a Google Earth image (April 2010). Each isocontour represents the area contributing to 25,50 and $75 \%$ of the observed sensible heat flux, respectively. One has to keep in mind that our averaging procedure favors daytime footprints which extend to typically $70 \mathrm{~m}$ upwind. The method gives less importance to nighttime footprints, which can extend up to $750 \mathrm{~m}$ upwind. During period P1 (Fig. 4a), the measurements were likely affected by shrubs upwind. The riparian forest located to the north of the site (which appears at the top of Fig. 4a) was far enough away and did not significantly influence the measurements. During this period, the footprint extension was limited to $70 \mathrm{~m}$. During period P2 (Fig. 4b), the wind direction varied considerably, but the footprint mainly remained over bare soil areas. Although daytime winds were mainly northeasterly winds, south-westerly night winds also significantly contributed to the footprint, as this wind direction lasted after sunrise. Thus, the "bas-fond" area (seasonally clogged headwater area, see Sect. 2.1), which is surrounded by trees, was partly included in the footprint. During this period, southerly winds were also observed from time to time. For these conditions too, some isolated trees likely contributed to the measured fluxes. During period P3 (Fig. 4c), the wind direction changed to the south-west. A $0.6 \mathrm{~m}$ high herbaceous layer had grown almost everywhere around the flux station in such a way that most of the shrubs were overlaid by grass, and the turbulent flows were only disturbed by some isolated trees. Finally, during period P4 (Fig. 4d), the vegetation was high $(\sim 2.5 \mathrm{~m})$ and the roughness length $(0.4 \mathrm{~m})$ and the displacement height $(1.6 \mathrm{~m})$ increased accordingly. For these vegetated conditions, the footprint areas were reduced by a factor of two compared with the one for P1, and the contributing areas were much closer to the sensors.

The contributions of fallows or annual crops to $75 \%$ of the footprint area were respectively $87,87,77$, and $97 \%$ for periods P1, P2, P3, and P4. However, the measurements 

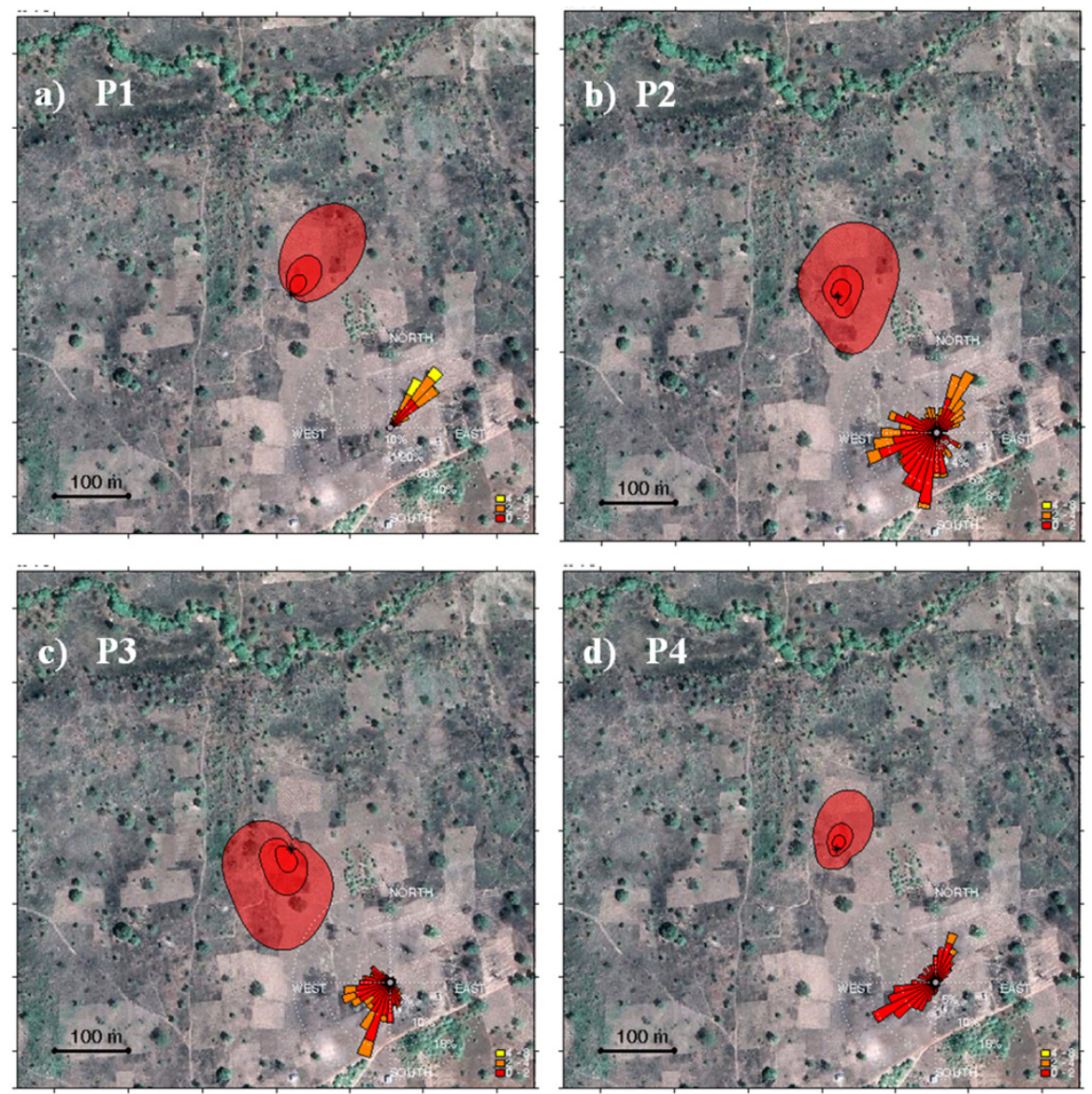

Fig. 4. Average footprint corresponding to each of the four selected periods superimposed over a Google Earth image (April 2010). Each isocontour delimits the area contributing to 25,50 , and $75 \%$ of the measured sensible heat flux, respectively. The corresponding wind rose is shown in each plot for three wind speed classes: 0-2 $\mathrm{m} \mathrm{s}^{-1}$ (red), 2-4 m s${ }^{-1}$ (orange) and 4-6 m s ${ }^{-1}$ (yellow). (a) P1 (18 January1 February); (b) P2 (26 February-11 March); (c) P3 (7-21 July) and (d) P4 (24 October-7 November).

were slightly more affected by the surrounding trees during period P3. From these analyses, we considered that the flux measurements presented below to be representative of the cultivated areas (mixed fields and fallows) for the four studied periods.

\subsubsection{Energy balance closure}

The energy balance closure was computed for the whole year and for the four 15-day periods. Scatter plots of $(\mathrm{LE}+H)$ vs. $\left(R_{\mathrm{n}}-G\right)$ are shown in Fig. 5 . At the 30 min timescale, the determination coefficient $r^{2}$ ranged from 0.90 to 0.97 , which indicated that most of the variability in the observed turbulent fluxes can be explained by the available energy. Considering the whole year (Fig. 5a), the coefficient of the linear regression $(0.84)$ indicated $16 \%$ of nonclosure, which corresponded to an underestimation of $(H+\mathrm{LE})$ as compared to $\left(R_{\mathrm{n}}-G\right)$. However, the energy balance closure varied, depending on the period of the year. During period P1, the determination coefficient was the highest $(97 \%)$, but the slope of the regression line was higher than 1 (1.1). This was due to midday values for which the $(H+\mathrm{LE})$ was larger than $\left(R_{\mathrm{n}}-G\right)$. This suggests an underestimation of the available energy, which can be explained by dust deposits on the radiation sensor. The sensor opacity impacts the net radiation, mostly when the sun is high in the sky. For values lower than $250 \mathrm{~W} \mathrm{~m}^{-2}$, the available energy and the turbulent fluxes were well correlated. However, the turbulent fluxes could be affected by errors that were not detectable. The uncertainty on the sensible heat flux for period P1 was estimated to $\pm 8 \%$, as the ratio of the standard deviation of the residuals (linear regression in Fig. 5b) divided by the maximum value of $H$.

During period P2, the slope of the regression line was 1.04, suggesting a good balance closure (Fig. 5c). The increased scattering for large $\left(R_{\mathrm{n}}-G\right)$ values was partly due to $R_{\mathrm{n}}$ measurements that were again partly affected by dust since the sensor had not been cleaned since the middle of the period. The uncertainty on turbulent fluxes for this period was $\pm 16 \%$. 

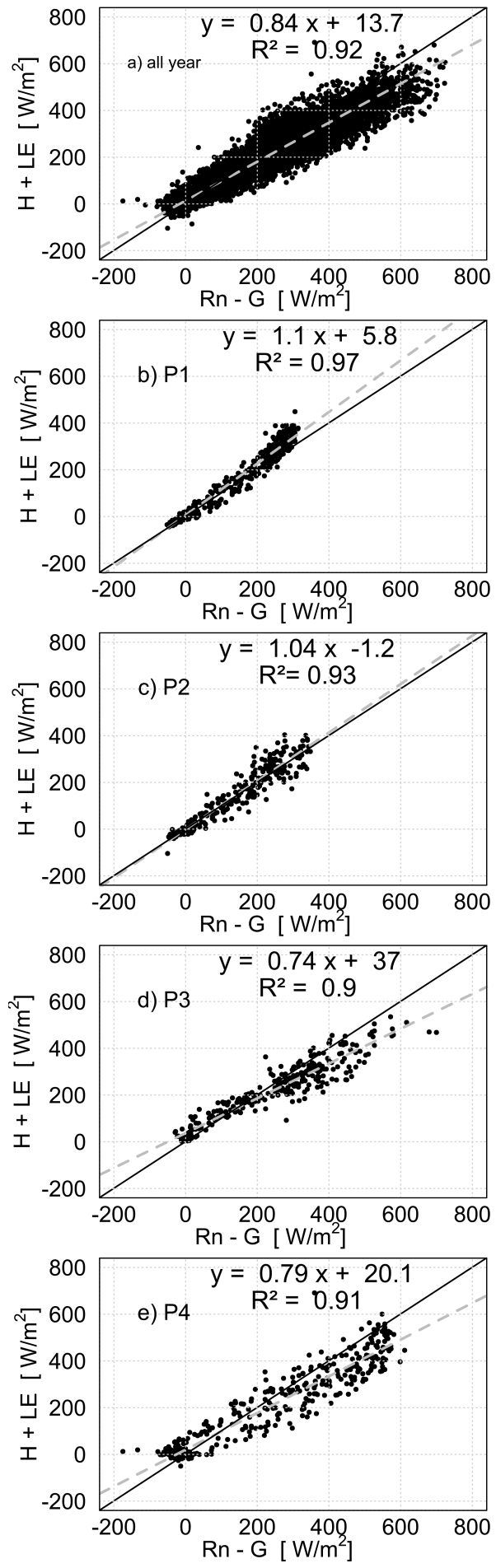

Fig. 5. Energy balance closure for the whole year (a) and the four studied periods: (b) P1 (18 January-1 February); (c) P2 (26 February-11 March); (d) P3 (7-21 July) and (e) P4 (24 October-7 November). The numbers of available half-hourly data which have been used to compute the regression line were 11 180, 673, 408, 293 and 444, respectively, for the whole year, P1, $\mathrm{P} 2, \mathrm{P} 3$, and $\mathrm{P} 4$.
For the last two periods, P3 and P4 (Fig. 5d and e), the regression coefficient was significantly lower than 1 , indicating a strong $(-25$ to $-20 \%)$ underestimation of turbulent fluxes. Because of systematic power shortages during the night, which stopped the gas analyzer until 09:00 UTC in period $\mathrm{P} 3$, the low values of turbulent fluxes $\left(<200 \mathrm{~W} \mathrm{~m}^{-2}\right)$ in Fig. 5d only corresponded to evening fluxes. These evening turbulent fluxes were larger than the available energy. A similar pattern was observed for period P4. However, morning values were available for $\mathrm{P} 4$, which produced a typical out-of-phase pattern (figure-eight-shaped), shown in Fig. 4d. This may be due to the vegetation cover, which acted as a buffer and induced a time shift in the daily peak of the soil heat flux. As a result, some hysteresis or asymmetry appeared. However, this canopy storage accounts for one or two tens of $\mathrm{W} \mathrm{m}^{-2}$, which does not explain the observed order of magnitude $\left(\sim 100 \mathrm{~W} \mathrm{~m}^{-2}\right)$ of the nonclosure. Previous studies have shown that secondary circulations seriously affect the eddy covariance flux measurements and thus may contribute to the unclosed energy balance, in particular above heterogeneous terrains (Inagaki et al., 2006; Kanda et al., 2004; Steinfeld et al., 2007). In our climatic context, Lohou et al. (2010) showed that the entrainment at the top of the boundary layer affected the entire boundary layer down to the surface. We argue that such a situation cannot explain the energy imbalance observed in P3 and P4 because entrainment impacts have been identified at night during transition periods when northern and southern wind conditions alternated. During the day, convective situations dominated and the thickness of the boundary layer remained large $(2 \mathrm{~km})$ as shown by Doukouré (2011). Thus, considering that the net radiation was unbiased during these two periods (sensor cleaned by rain), the three other energy budget terms cumulated the imbalance proportionally to their absolute values.

Although imperfect, the energy balance closure presented in this study was similar or better than what was commonly found with the eddy covariance method in previous studies (Wilson et al., 2002), especially in the western African regions (Mauder et al., 2007; Bagayoko et al., 2007; Brümmer et al., 2008; Ramier et al., 2009; Timouk et al., 2009). In conclusion, we considered the consistency and quality of the various flux components to be satisfactory.

\subsection{Seasonal and daily dynamics of energy budget terms}

The annual cycle of the four energy budget components is shown in Fig. 6. The shaded grey areas show the large daily amplitude. One can notice the low values of the net radiation in dry season $\left(<500 \mathrm{~W} \mathrm{~m}^{-2}\right)$. The sensible heat flux $H$ over bare soil had a rather steady behavior, similar to the net radiation. The daily mean, $R_{\mathrm{n}}$, and the peak value reached 80 and $330 \mathrm{~W} \mathrm{~m}^{-2}$, respectively. During the wet season, $R_{\mathrm{n}}$ was as high as $800 \mathrm{~W} \mathrm{~m}^{-2}$, but had a large day-to-day variability due to the cloud cover; the average sensible heat flux was half the value of the previous season. Then, $H$ increased slowly at 

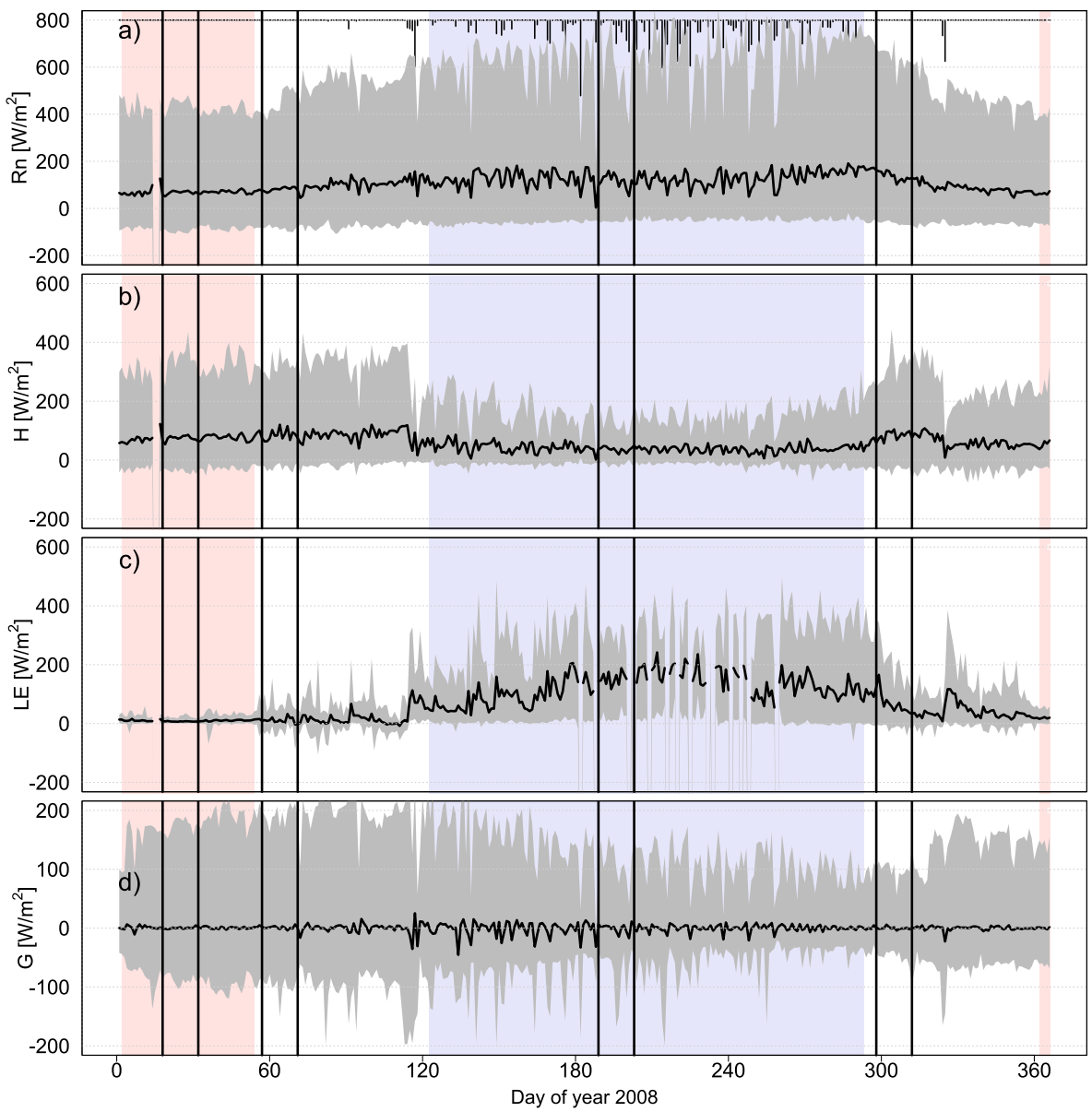

Fig. 6. Seasonal variation of energy fluxes: daily average (black line) and daily range (grey shaded areas) of (a) net radiation $\left(R_{\mathrm{n}}\right)$, (b) sensible heat flux $(H)$, (c) latent heat flux (LE) and (d) soil heat flux $(G)$. The rose and blue shaded areas highlight the dry and wet seasons, respectively. The vertical bars indicate the four studied periods (same as Fig. 2).

the end of the wet season when vegetation dried and rainfall stopped. The latent heat fluxes, LE, had an opposite behavior with very low values during the dry and transition seasons, and high values during the wet season (daily maximum values up to $450 \mathrm{~W} \mathrm{~m}^{-2}$ ). The soil heat flux showed a wide daily amplitude, but the daily average remained close to zero. When rainfall occurred on hot soil surface (DOY 95, Fig. 6d), sharp drops in the ground heat fluxes were observed; these negative values corresponded to a rapid release of energy that fed evaporation processes.

In light of the energy fluxes time series, each period from P1 to P4 was well representative of the corresponding season. This is illustrated in Fig. 7 where box plots of midday (10:00-14:00 UTC) sensible heat fluxes were compared for each period and each season. The median value of period $\mathrm{P} 1$ was slightly higher than for the whole dry season $\left(+20 \mathrm{~W} \mathrm{~m}^{-2}\right)$, but the difference was less than $7 \%$ of midday value. The sensible heat flux variability during P2 was largely reduced in comparison to the whole moistening season because a period without any rainy event was chosen.
Nevertheless, the median value of P2 was close to the seasonal median value. For the period P3, sensible heat fluxes were at their lowest daily values as also shown in Fig. 6b. Finally, the drying season was hardly captured with a single 15day period because climatic and surface conditions changed greatly during this transition season. To summarize, P1 and P2 (P3) represented the highest (lowest) sensible heat flux regime, while $\mathrm{P} 4$ was only representative of the beginning of the wet-to-dry transition season with decaying herbaceous vegetation. Although it cannot be generalized to the entire wet-to-dry season, the $\mathrm{P} 4$ period characterizes a long-lasting surface drying episode, with vegetation in senescent phase, which can be useful for both the parameterization and the evaluation of land surface models.

The following paragraphs focus on the four 15-day periods, and more precisely on the daily cycles of $R_{\mathrm{n}}, H, \mathrm{LE}$ and $G$. In order to draw robust conclusions, daily composites of each energy budget term have been computed. They are reported in Fig. $8 \mathrm{a}-\mathrm{d}$. Table 2 regroups daily statistical 


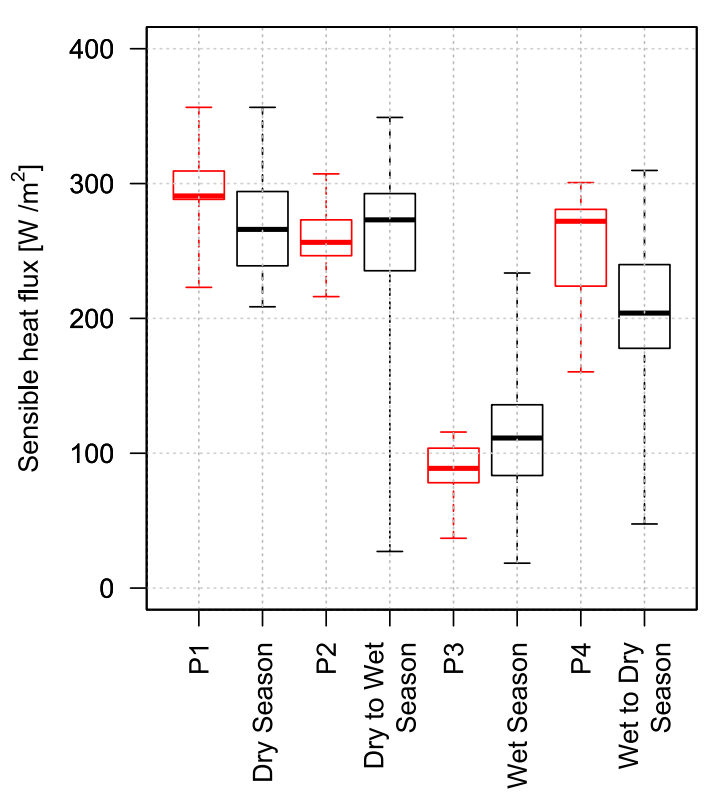

Fig. 7. Box plots of midday sensible heat flux $(H)$ for the four studied periods (red) and the full corresponding season (black). Each box represents the median, the 25th, and the 75th quartiles; the whiskers indicate the maximum and the minimum values of $H$. Period P1 (18 January-1 February); period P2 (26 February11 March); period P3 (7-21 July) and period P4 (24 October7 November).

characteristics including daily means, min and max daily values and their respective standard deviation for each period.

For period P1 (Fig. 8a), $R_{\mathrm{n}}$ shows a "bell-shaped" pattern typical of clear-sky conditions. However, $R_{\mathrm{n}}$ reached a low daily maximum $\left(442 \pm 29 \mathrm{~W} \mathrm{~m}^{-2}\right)$ due to the high aerosol concentration brought by the Harmattan wind, the strong surface albedo $(\sim 0.2)$, and the large surface temperature amplitude $\left(18-50{ }^{\circ} \mathrm{C}\right.$ ) (not shown). The minimum was $-96 \pm 7 \mathrm{~W} \mathrm{~m}^{-2}$, and the maximum value was reached just before noon because of large $\mathrm{LW}_{\text {net }}$ amplitude that increased until 13:30 UTC and reached $-170 \mathrm{~W} \mathrm{~m}^{-2}$ (Fig. 3b). During this period, $G$ was in phase with the daily course of the net radiation. It ranged between $-88 \pm 6 \mathrm{~W} \mathrm{~m}^{-2}$ at night, and $174 \pm 11 \mathrm{~W} \mathrm{~m}^{-2}$ just before noon (Table 2). Despite the high surface temperature and hence the high temperature gradient in the soil, $G$ was limited by the low thermal conductivity of the dry soil $\left(0.56 \mathrm{~W} \mathrm{~m}^{-1} \mathrm{~K}^{-1}\right)$. During nighttime, $G$ did not compensate $R_{\mathrm{n}}$ entirely, and negative sensible heat fluxes were observed $\left(-26 \pm 10 \mathrm{~W} \mathrm{~m}^{-2}\right)$. During daytime, the sensible heat flux $H$ was also bell-shaped, but shifted slightly after noon. As the surface was hot and dry, the available energy was mainly converted into $H$, which reached its maximum of $326 \pm 40 \mathrm{~W} \mathrm{~m}^{-2}$ at 12:30 UTC. It remained positive one hour later than $R_{\mathrm{n}}$ since the atmospheric stability systematically became positive at 18:00 UTC during this period as shown in Fig. 9a. By contrast, LE was low but nonzero, although the soil was bare and the surface was dry. Its daily maxi- mum value was $17 \pm 4 \mathrm{~W} \mathrm{~m}^{-2}$. This nonnegligible amount of evapotranspiration may have originated from the transpiration of shrubs and sparse trees, located northward as shown in the footprint analysis (Fig. 4a). However, the slight decrease observed in the $0-30 \mathrm{~cm}$ soil water content during this period (Fig. $2 \mathrm{~g}$ ) suggests a possible contribution of soil evaporation.

The $\mathrm{P} 2$ period is rather similar to period $\mathrm{P} 1$, since the soil was still bare. During the $\mathrm{P} 2$ period no rainfall occurred and air and surface temperature increased, which increased the time shift between the sensible heat flux and the net radiation. At night, the absolute sensible heat flux was lower because of weaker wind and the weaker absolute temperature gradient (see Fig. 14d and Sect. 3.5). Changes in wind direction and moisture supply from night monsoon flow did not affect surface processes, but increased the day-to-day variability of the energy fluxes since the footprint explored all the directions around the sensor (Fig. 4b). This is particularly obvious on latent heat flux statistics (Table 2). However, the slight increase of LE could be attributed to an increase in shrub activity. Indeed, Seghieri et al. (2009) have shown that in Sudanian climate region, shrub flowering is probably linked to the rise of air temperature, which occurs from February to May in the study region. Bearing in mind that flowering involves a significant activity, this means that shrubs should have a higher transpiration activity in $\mathrm{P} 2$ and could also explain the increase in latent heat flux between P1 and P2. Thus, the latent heat flux was low (Fig. 8b) but not null in the dry season on our site, even if the soil surface remained dry.

During P3 (Fig. 8c), the occurrence of rainfalls changed both atmospheric and surface conditions dramatically. The soil remained wet due to regular rainfalls and the annual vegetation was well established. As a consequence, the surface temperature (not shown) had a low daily amplitude (25$\left.32{ }^{\circ} \mathrm{C}\right)$ and the net radiation was lower $\left(-37 \pm 13 \mathrm{~W} \mathrm{~m}^{-2}\right)$ for the entire night until 06:00 UTC, as compared to the previous periods. The cloud cover was lower in the afternoon than in the morning, and the maximum daily $R_{\mathrm{n}}$ was observed at 13:00 UTC. The daily cycle of $R_{\mathrm{n}}$ directly affected turbulent fluxes, which exhibited the same midday shape. The surface conditions were favorable to LE, which was the main consumer of the available energy. LE peaked at $259 \pm 58 \mathrm{~W} \mathrm{~m}^{-2}$. However, sensible and ground heat fluxes were nonnegligible, with respective maximum daily values of $103 \pm 38 \mathrm{~W} \mathrm{~m}^{-2}$ and $88 \pm 35 \mathrm{~W} \mathrm{~m}^{-2}$. It was also quite surprising to observe positive latent heat fluxes in the evening until midnight (Fig. 8c) (no LE observation was available later in the night). As $\left(\overline{w^{\prime} q^{\prime}}\right)$ covariance was always positive, this was not attributed to flux corrections. During the night, the stability was slightly positive $(0.1 \pm 0.1)$, which characterized a near-neutral surface layer (Fig. 9c). This process may be fed by the release of energy stored into the ground since available energy is positive until midnight (i.e. $R_{\mathrm{n}}>G$ in Fig. 8c). Mauder et al. (2007) also observed positive latent heat fluxes at night in Nigeria, which were attributed to the advection of dry air over a wet surface. However, in our case 

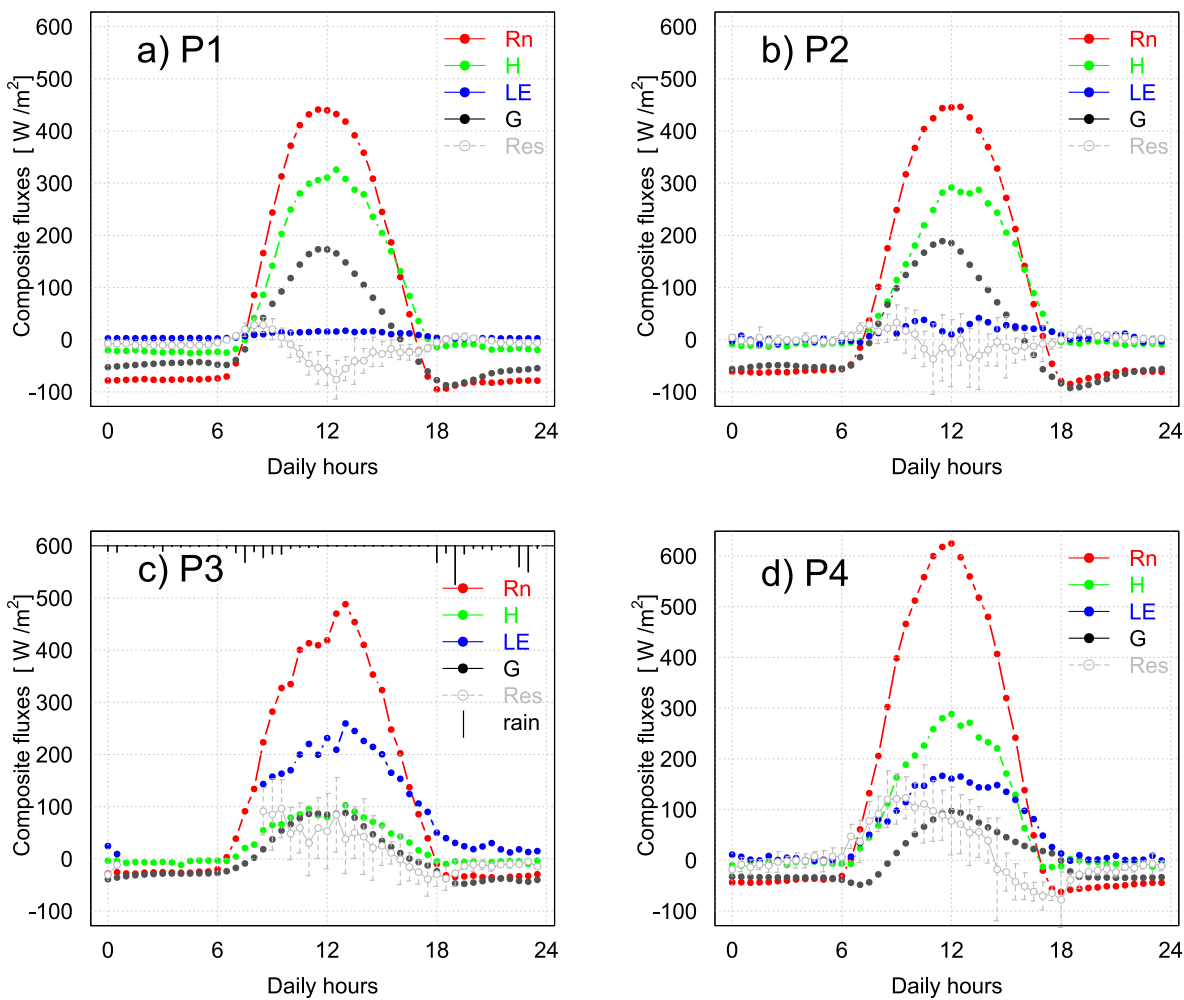

Fig. 8. Composite diurnal cycle of the energy budget components for the four periods: (a) P1 (18 January-1 February); (b) P2 (26 February11 March); (c) P3 (7-21 July) and (d) P4 (24 October-7 November). Net radiation $\left(R_{\mathrm{n}}\right.$, red), sensible heat flux ( $H$, green), latent heat flux (LE, blue), soil heat flux $\left(G\right.$, black) and the residual of the energy balance equation ( $\operatorname{Res}=R_{\mathrm{n}}-G-H-\mathrm{LE}$, grey); the grey brackets represent the residual standard deviation.

the positive latent heat fluxes during nighttime were not attributable to dry air advection as no changes in wind direction were observed during P3. Incomplete stomata closure during the night in $\mathrm{C} 4$ species can occur in response to a water-vapor deficit, temperature, or water or nutrient availability (Caird et al., 2007), any of which can induce nighttime transpiration (Snyder et al., 2003). Nevertheless, stomatal conductances have to be directly measured to confirm this assertion and to quantify the transpiration contribution observed in the latent heat fluxes at night.

During P4, clear-sky conditions prevailed again, but the net radiation rapidly decreased (Fig. 6a) because of the lower solar radiation at his period of the year. In addition, the surface temperature increased, which lowered the longwave net radiation (Fig. 3b). The daily cycle of $R_{\mathrm{n}}$ reached its maximum at noon $\left(625 \pm 78 \mathrm{~W} \mathrm{~m}^{-2}\right)$ as well as the other terms of the energy budget. During this period, the soil and vegetation were drying, and the daily maximum of the latent heat flux was continuously decreasing (Fig. 6c). At night, LE fell to zero one hour after $R_{\mathrm{n}}$ turned negative. This behavior is different from the previous period P3 because night stability (Fig. 9d) was near unity in P4 while it was near neutral during period P3. The daily dynamics of $G$ showed a two-hour delay in the morning in comparison to $R_{\mathrm{n}}$. This explains the out-of- phase pattern already observed on the energy budget closure (Fig. 5e). We assumed that this phase shift was caused by the height of the vegetation layer $(2.5 \mathrm{~m})$, which induced a delay in soil surface warming, whereas turbulent fluxes and net radiation followed the dynamics of the skin temperature of the top of the canopy (Santanello and Friedl, 2003). However, one has to remember that, as the surface conditions changed during this season, little generality can be derived from the analysis of this $\mathrm{P} 4$ period.

\subsection{Characterization of surface processes}

In this section, the energy partitioning is analyzed and discussed with classical synthetic variables such as the evaporative fraction, the Bowen ratio and the surface conductance, in order to identify specific functioning characteristics of this Sudanian cultivated area and to derive useful parameters for land surface modeling.

\subsubsection{Energy partitioning and surface characteristics}

The midday average evaporative fraction (10:00-14:00 UTC) (EF) is presented in Fig. 10a for the examination of the seasonal variations in energy partitioning related to surface conditions. Two contrasting surface behaviors were 

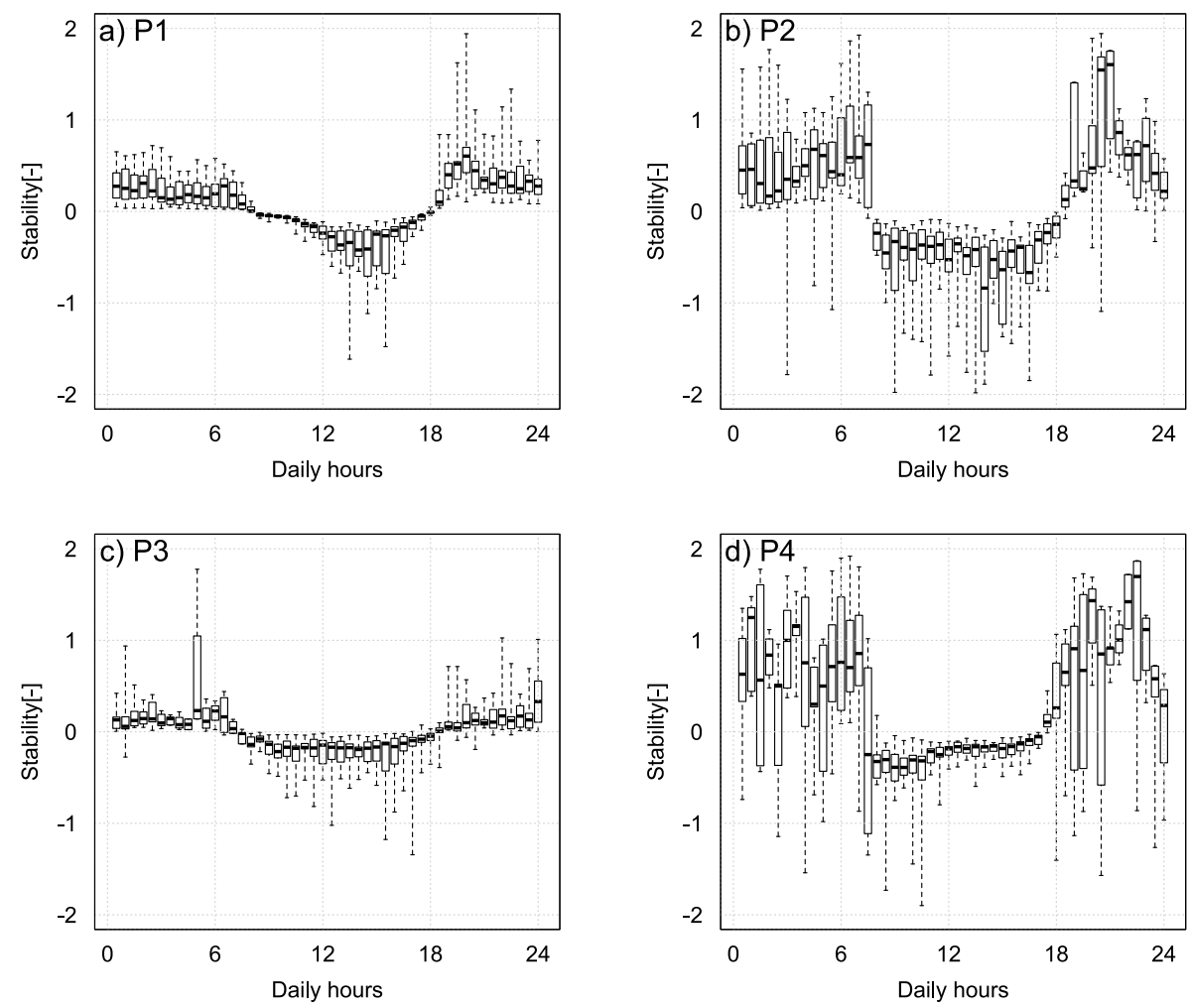

Fig. 9. Box plots of composite Monin Obhukov Stability at Nalohou site during (a) period P1 (18 January-1 Feruary); (b) period P2 (26 February-11 March); (c) period P3 (7-21 July) and (d) period P4 (24 October-7 November). Each box represents the median and the 25 th and 75 th quartiles; the whiskers indicate the maximum and the minimum values of the stability.

identified. During the dry season, from January to the end of February, very low evaporation occurred $(\mathrm{EF}=0.08)$; during this period, the soil was bare and dry (Fig. $2 \mathrm{~g}$ ). By contrast, EF remained high (close to 0.75 ) and steady in the second part of the wet season, for 4 months as from the monsoon onset (22 June 2008; DOY 174). In this period, the soil water content exceeded $0.12 \mathrm{~cm}^{3} \mathrm{~cm}^{-3}$ and EF was not affected by the soil water content or the vegetation development.

Between these two periods, EF was highly variable in response to isolated rainfall events, which usually occur during the transition periods. These events induce large fluctuations in soil water availability and vegetation stress, which drive the vegetation development in the dry-to-wet period. The dynamics of EF associated with isolated rainfall events are clearly illustrated in Fig. 10a; the heavy rainfall that occurred on DOY 325 (20 November 2008) over bare soil and after the vegetation burning resulted in an instantaneous increase of EF from 0.2 to 0.75 , followed by a 10 -day decrease. A more detailed analysis of the surface response and recovery associated with rainfall events is presented in Lohou et al. (2013) for all AMMA-CATCH flux sites.

The Bowen ratio plotted on the same graph (Fig. 10a) shows the opposite behavior. The decrease of $\beta$ starting around DOY 30 (30 January 2008) is interpreted as the signature of the transpiration of the ligneous vegetation, in a period where neither rain nor change in soil moisture was observed. Indeed, the maximal value of $\beta$ was phased with the renewal of trees or shrubs leaves (Seghieri et al., 2009), and the increase in LE was synchronous with leaf development.

The observed conductance, $G_{\mathrm{s}}$, and the decoupling factor, $\Omega$, are plotted in Fig. 10b for the whole year. During the dry season, when the soil was bare, $G_{\mathrm{s}}$ was less than $1 \mathrm{~mm} \mathrm{~s}^{-1}$ and the decoupling factor was almost null, meaning that surface and the atmosphere were coupled. Because of the high instability of the surface layer near the ground, the mixing imposed the atmospheric water vapor deficit to the air layer close to the ground surface. After the monsoon onset (as from DOY 174), when the vegetation had grown enough and the soil moisture no longer limited the vegetation activity, the canopy conductance reached $20 \mathrm{~mm} \mathrm{~s}^{-1}$ with a maximum value of about $30 \mathrm{~mm} \mathrm{~s}^{-1}$. These values are consistent with the usual values for crops, as observed by Bagayoko et al. (2007) in Burkina Faso. The decoupling factor was still far from unity and remained below 0.7 . This means that a full decoupling between the atmosphere and the canopy water vapor deficit was never observed, even when the vegetation was fully developed; the atmosphere was unstable enough to mix the air inside the canopy with the boundary layer. At the end of the wet season, the decrease of soil moisture and LAI 


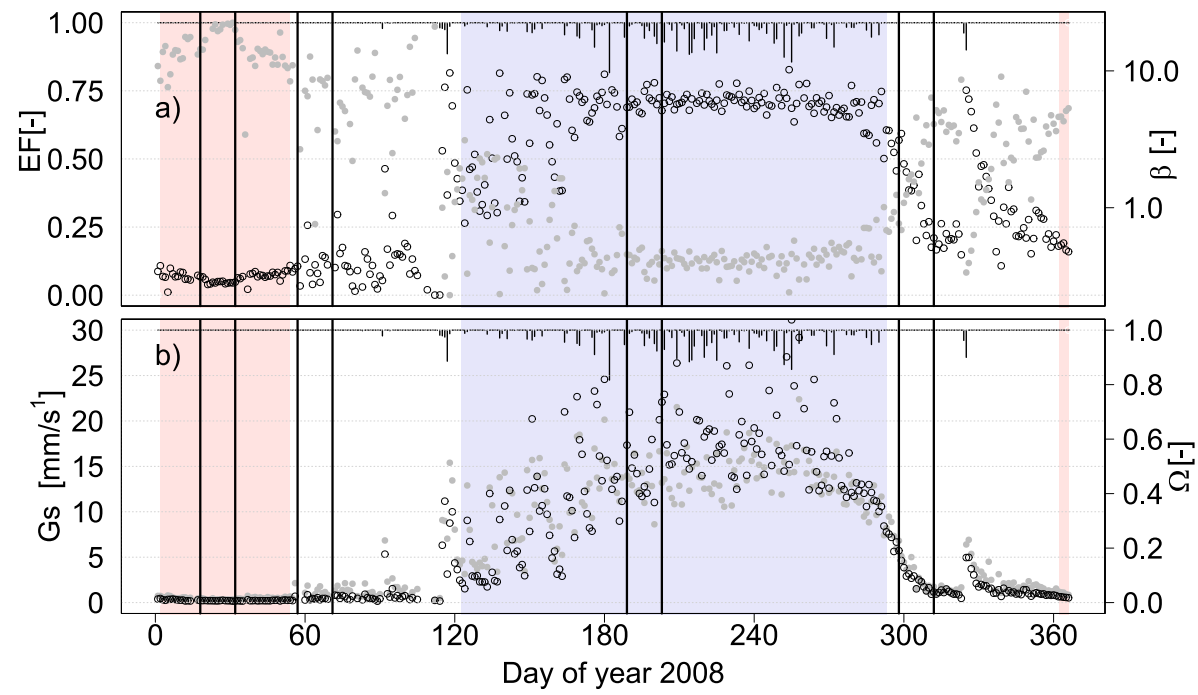

Fig. 10. Midday (10:00-14:00 UTC) average of (a) evaporative fraction (EF) (black circle - left axis), Bowen ratio $(\beta)$ (grey points - right axis); (b) surface conductance $\left(G_{\mathrm{S}}\right)$ (black circle - left axis) and decoupling coefficient $(\Omega)$ (grey points - right axis). The rose and blue shaded areas highlight the dry and wet seasons, respectively. The vertical bars delimit the four studied periods (same as Fig. 2).

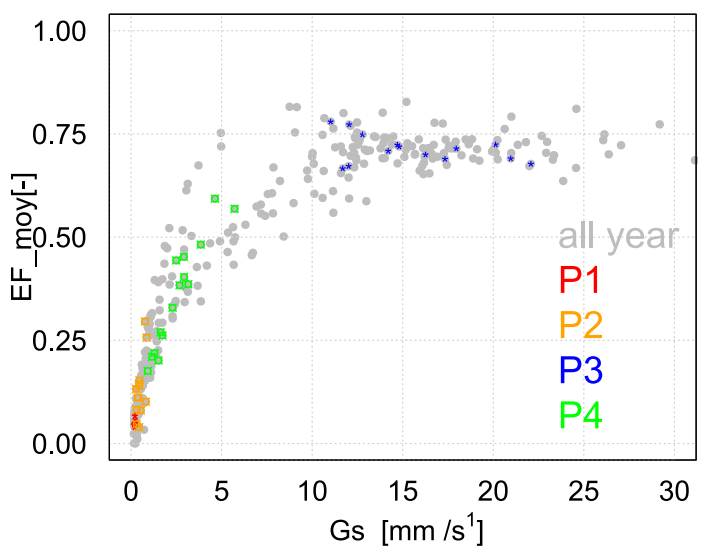

Fig. 11. Midday (10:00-14:00 UTC) evaporative fraction (EF_moy) versus midday surface conductance $\left(G_{\mathrm{S}}\right)$ for the whole year (grey) and for the four periods. P1: 18 January-1 February (red); P2: 26 February-11 March (orange); P3: 7-21 July (blue) and P4: 24 October-7 November (green).

resulted in a simultaneous decrease of both the conductance and the decoupling factor.

To analyze the sensitivity of the energy partitioning to the surface conditions along the annual cycle, the relationship between EF and $G_{\mathrm{s}}$ at midday was plotted in Fig. 11. The graph shows that EF was highly influenced by the surface conductance when $G_{\mathrm{s}}$ values were lower than $10 \mathrm{~mm} \mathrm{~s}^{-1}$, as observed for periods P1, P2 and P4. By contrast, EF was no longer driven by the surface conditions when $G_{\mathrm{S}}$ was higher than this threshold value, as observed in the $\mathrm{P} 3$ period, and more generally after the onset; the evapotranspiration was

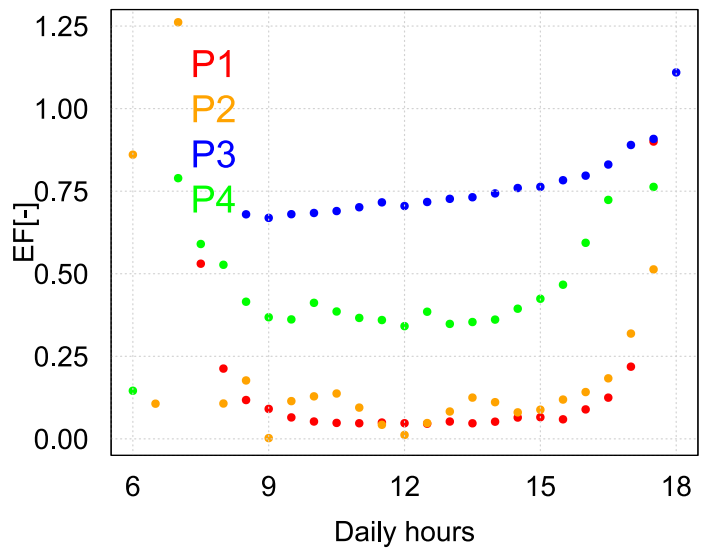

Fig. 12. Daily cycle of evaporative fraction (EF) for the four periods (same as Fig. 11).

only driven by the atmospheric demand and by the available solar radiation.

\subsubsection{Daily cycle of the evaporative fraction (EF)}

The composite daily cycle of EF from 06:00 to 18:00 UTC (Fig. 12) shows a typical "concave up" shape with a minimum around 12:00 UTC. In the morning before 09:00 UTC, $\mathrm{EF}$ is noisy because negative sensible or latent heat fluxes can lead to low values of the sum $(H+\mathrm{LE})$, which leads to large $\mathrm{EF}$ values.

During periods P1 and P2, EF was very low and showed negligible differences during the day, except at sunrise and sunset. Although clear in Fig. 8a and b, the time shift observed on the sensible heat fluxes has no marked effect on 

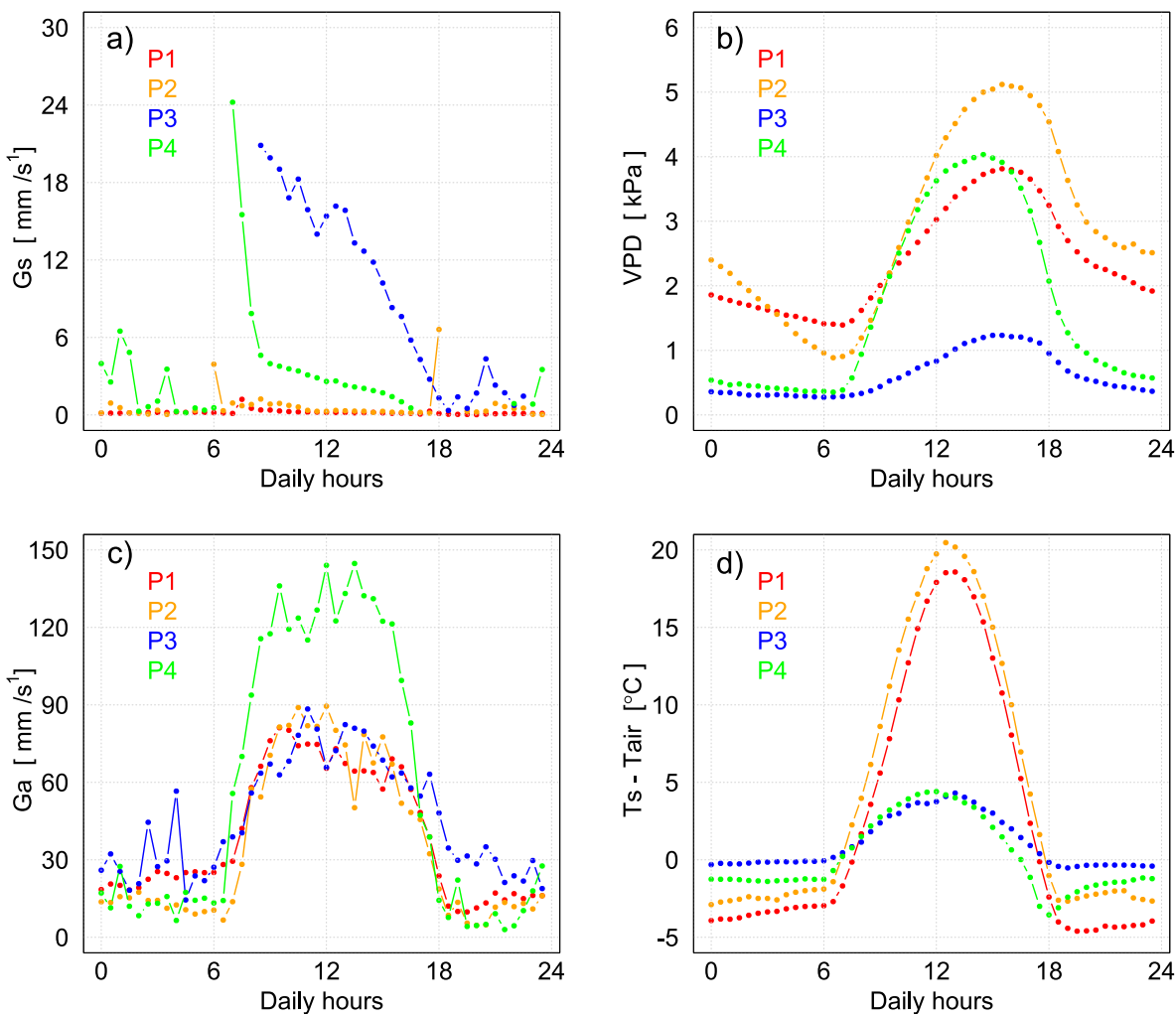

Fig. 13. Daily cycle of the (a) surface conductance $\left(G_{\mathrm{S}}\right)$, (b) water vapor deficit (VPD), (c) aerodynamic conductance $\left(G_{\mathrm{a}}\right)$ and $(\mathbf{d})$ temperature gradient between surface and air $\left(T_{\mathrm{S}}-T_{\text {air }}\right)$ for the four periods P1: 18 January-1 February (red); P2: 26 February-11 March (orange); P3: 7-21 July (blue); and P4: 24 October-7 November (green).

the daily increase of EF (Fig. 12). In period P3, EF increases continuously during daytime from 09:00 UTC (0.69) to 16:00 UTC (0.80). Gentine et al. (2007) extensively studied EF and simulated an increase of EF at the end of the afternoon due to a thermal inversion into the canopy, when the temperature of the vegetation was greater than that of the soil. Such inversions, characterized by EF $>1$, were not really observed in Nalohou except very late in the afternoon (18:00 UTC) during P3. This diurnal increase in EF was better explained by Gentine et al. (2012), who also showed that it can be due to a time shift between sensible and latent heat fluxes. Such a time lag was observed in period P3 when the maximum value of the latent heat flux was observed later than that of the sensible heat flux. Such a behavior resulted from a slower increase of the surface temperature in the morning as compared to the increase in the net radiation. This shift was caused by the high evapotranspiration rate during period $\mathrm{P} 3$, which attenuated the diurnal range of the sensible heat flux. During period P4, the diurnal cycle of EF shows a pronounced but typical $U$ shape, resulting in the afternoon from the rapid decrease in the sensible heat flux before 18:00 UTC (Fig. 8d) because of the rapid radiative cooling (see Fig. 13d) and the subsequent stratification (Fig. 9d).
In order to analyze the flux partitioning and the surface control on evapotranspiration more precisely, the average daily cycles of aerodynamic $\left(G_{\mathrm{a}}\right)$ and soil/canopy $\left(G_{\mathrm{s}}\right)$ conductance were plotted in Fig. 13 for the four periods. For periods $\mathrm{P} 1$ and $\mathrm{P} 2$ the soil was bare, $G_{\mathrm{a}}$ was quite similar except between 02:00 and 06:00 UTC (Fig. 13c), and $G$ was very low all day long $\left(<01 \mathrm{~mm} \mathrm{~s}^{-1}\right)$ as already discussed. During the wet period (P3), $G_{\mathrm{a}}$ had the same daily magnitude as it did during preceding periods and reached $90 \mathrm{~mm} \mathrm{~s}^{-1}$. However, $G_{\mathrm{a}}$ remained as high as $30 \mathrm{~mm} \mathrm{~s}^{-1}$ during the night. This means that the atmospheric resistance to vapor transfer was low at night during this period, and thus that turbulent surface-atmosphere exchanges, enhanced by wind shear, were possible, as shown in Fig. 8c for LE. During period P3, when the vegetation was fully developed, the daily cycle of $G_{\mathrm{s}}$ was clearly dissymmetric, with higher values in the morning (nighttime values were not available). For period $\mathrm{P} 4$ (wetto-dry transition), $G_{\mathrm{a}}$ at midday was much higher than in the other periods, due to a higher roughness length when herbaceous vegetation was high. In this period, $G_{\mathrm{a}}$ was also the lowest during the night because of higher stability (Fig. 9d). The surface conductance, $G_{\mathrm{s}}$, of the senescent vegetation was high $\left(24 \mathrm{~mm} \mathrm{~s}^{-1}\right)$ in the morning (07:00 UTC) and similar to the one observed in P3, but it decreased rapidly. It was four 


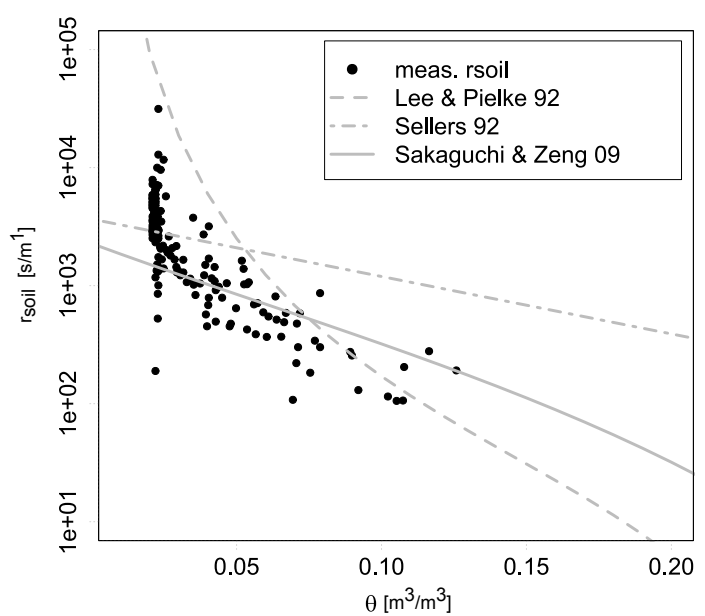

Fig. 14. Observed bare soil resistance $\left(r_{\text {soil }}\right)$ vs. $5 \mathrm{~cm}$ soil moisture $(\theta)$ (black dots), and Lee and Pielke (1992) (dashed line), Sellers et al. (1992) (dash dotted line), and Sakaguchi and Zeng (2009) (with curvature parameter $w=5$, thin line) soil resistance models.

times lower than in P3 at 09:00 UTC; the midday $G_{\mathrm{s}}$ value was much lower $\left(3 \mathrm{~mm} \mathrm{~s}^{-1}\right)$ than during period $\mathrm{P} 3$.

Hereafter, the surface conductance observations were compared to modeling results of specific processes such as bare soil evaporation and canopy transpiration. The aim of this comparison is to identify the respective contributions of aerodynamic, soil, stomata, and roots conductances, and to check the ability of standard models to reproduce these observations.

\subsection{Evaluation of surface conductance models}

The surface conductance is the sum of the canopy and the bare soil conductances, which have specific formulations and may account for different water vapor deficits. For bare soils, the surface water vapor conductance is mainly limited by the soil resistance $\left(r_{\text {soil }}\right)$, which depends on the soil moisture, whereas the canopy conductance is regulated by more complex photosynthetic processes, soil water availability, etc. We took advantage of the contrasting surface conditions found on our experimental plot to explore the soil resistance $\left(r_{\text {soil }}\right)$ behavior when the soil was bare at the beginning of the year. The canopy conductance was assessed when the vegetation had grown, and can be modeled by a "big leaf" approach (Jarvis and McNaughton, 1986). For the Nalohou site, these conditions were achieved in the second part of the rainy season. During this period, light extinction in the vegetation cover prevented significant soil evaporation.

The soil resistance $\left(r_{\text {soil }}=1 / G_{\mathrm{s}}\right)$ for bare soil conditions, computed from Eq. (4), was plotted against the surface soil moisture measured at $5 \mathrm{~cm}$ depth in Fig. 14. The soil resistance increased rapidly when the soil moisture reached the residual saturation $\left(0.02 \mathrm{~m}^{3} \mathrm{~m}^{-3}\right)$. For higher surface soil moisture, between 0.02 and $0.15 \mathrm{~m}^{3} \mathrm{~m}^{-3}$, it decreased fol-

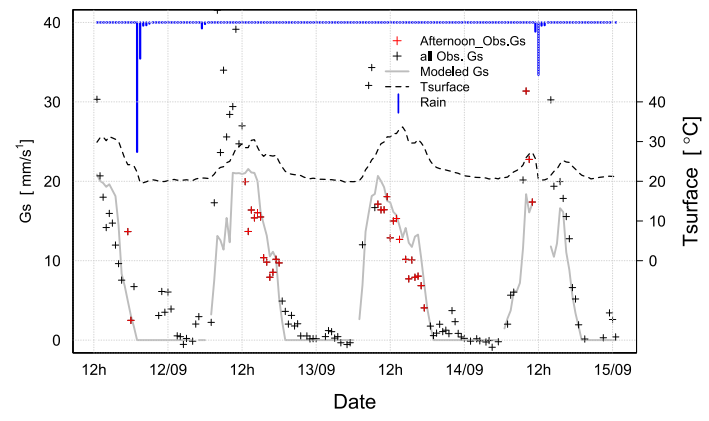

Fig. 15. Temporal variations of observed (crosses) and modeled (grey line) surface conductance, $\left(G_{\mathrm{S}}\right)$, for three typical days in the wet season (11 to 15 September). The red crosses show the observations selected for further analysis. The blue vertical lines represent the rainy events, and the dashed line the surface temperature (right axis).

lowing a power law, as observed by previous authors (van de Griend and Owe, 1994; Aluwihare and Watanabe, 2003). The $r_{\text {soil }}$ modeling laws proposed by Sellers et al. (1992), Lee and Pielke (1992), and Sakaguchi and Zeng (2009) were superimposed in Fig. 14. It can be seen that Sellers' formulation overestimates $r_{\text {soil }}$ for all soil moisture values. Thus, this model will systematically underestimate bare soil evaporation. Similarly, the Lee and Pielke $r_{\text {soil }}$ function underestimates evaporation, but for low soil moisture values only. The Sakaguchi and Zeng function fits much better with the data. However, none of these models were able to reproduce the high values of the bare soil conductance observed for dry conditions, when the soil matric potential was high, but this would only slightly affect the simulation of bare soil evaporation since very little water is available at the surface for these conditions.

The dynamics of the surface conductance $\left(G_{\mathrm{s}}\right)$ for vegetated surface conditions (wet season) was simulated with the Ball-Berry stomata conductance model (Collatz et al., 1992), and compared to $G_{\mathrm{s}}$ estimated from the observations. The period considered spans from DOY 189 to DOY 313 and includes P3. Three typical days in the wet season have been chosen to illustrate the observed and simulated $G_{\mathrm{S}}$ dynamics in relation to rainfall (Fig. 15). During these three days, $G_{\text {s }}$ was well simulated in the second half of the day, but large $G_{\text {s }}$ peaks were observed after the rainy events (12 and 14 September), and also in the morning whereas no rain occurred the day before (13 September). As these peaks were not simulated by the Ball-Berry stomata conductance model, we hypothesized that they were caused by evaporation of either intercepted water or dew deposits; these processes were not accounted for in the conductance model. Unfortunately, as eddy covariance data were not available in the morning during period P3, the systematic dew deposition cannot be assessed during this period. 
Symmetric (12 September) and dissymmetric daily patterns of simulated $G_{\mathrm{s}}$ were observed (Fig. 15) with higher values in the morning (13 September). This dissymmetric shape was also observed during one of the 15-day periods, $\mathrm{P} 3$ (Fig. 13). As stated by Collatz et al. (1992), a temperatureinduced limitation of photosynthesis can occur when the temperature of the vegetation is higher than $30^{\circ} \mathrm{C}$. This temperature, calculated from longwave radiations, was frequently higher than $30^{\circ} \mathrm{C}$ in the early afternoon in $\mathrm{P} 3$ and $\mathrm{P} 4$ (not shown). Associated with the evaporation of intercepted water, we concluded that these high temperatures were responsible for the higher $G_{\mathrm{S}}$ values in the morning as compared to the afternoon observed on Fig. 13a for periods P3 and P4. The model seems to reproduce this effect well.

To quantify the ability of the Ball-Berry model to simulate the conductance beyond these 3 days, the observed vs. simulated $G_{\mathrm{S}}$ values were plotted for the whole vegetated period (Fig. 16). To remove dew or rainfall effect, the three hours after sunrise and the six hours after rainfall have been excluded from the analysis. Figure 16 shows that the conductance was satisfactorily simulated $\left(r^{2}=0.92\right)$ by the Ball-Berry model with the default $\mathrm{C} 4$ grass parameter set. Then we can conclude that the Latent heat flux was mainly supplied by transpiration. The temperature effect was also well reproduced and has to be taken into account in SVAT (soil-vegetationatmosphere transfer) modeling. Any SVAT simulation producing a biased leaf temperature will also simulate a biased evapotranspiration rate. In particular in this Sudanian region, the daytime leaf temperature varies around the most efficient temperature limitation $\left(\sim 30^{\circ} \mathrm{C}\right)$. Thus the photosynthesis regime is often close to its maximum, and any negative or positive bias in the leaf temperature will lead to an underestimation of the canopy conductance, and thus of the transpiration.

\section{Conclusions}

The paper analyzes a one-year surface energy budget data set, collected in 2008 over a cultivated area in northern Benin (western Africa). To the authors' knowledge, this is the first time an entire seasonal cycle of surface fluxes was analyzed for this Sudanian region. The study shows a contrasting behavior of all the energy budget components, depending on the phases of the rainy season.

In the dry season (January-February), the mean daily sensible heat flux $\left(72 \mathrm{~W} \mathrm{~m}^{-2}\right)$ represented $92 \%$ of the available energy because of prevailing bare soil conditions. A low but persistent latent heat flux was measured and attributed to the transpiration of a few neighboring sparse bushes, possibly fed by the water table. In the wet season (May-October), the mean daily evapotranspiration was highly variable (from 50 to $200 \mathrm{~W} \mathrm{~m}^{-2}$ ), in response to the variability of the atmospheric forcing; the evaporative fraction (EF) was variable accordingly, ranging from 0.25 to 0.8 . After the monsoon on-

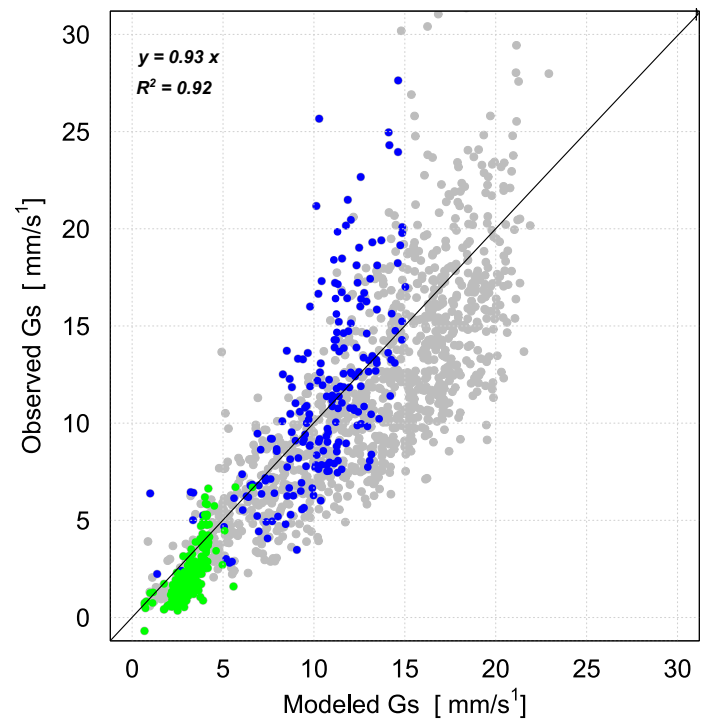

Fig. 16. Afternoon half-hourly observed vs. modeled (Ball-Berry) surface conductance $\left(G_{\mathrm{S}}\right)$ during the vegetated period (DOY 189DOY 313) (grey dots). Superimposed blue (resp. green) dots stand for period P3 (resp. P4). P3 (7-21 July) and P4 (24 October7 November).

set (22 June), EF reached a constant value $(\mathrm{EF}=0.75)$, and soil moisture no longer limited transpiration (surface conductance $>10 \mathrm{~mm} \mathrm{~s}^{-1}$ ), which was only controlled by the atmospheric water vapor deficit. EF slightly increased during the day because evapotranspiration was delayed due to heating processes. Latent heat fluxes were observed until midnight, which evidences the persistence of stomata activity in the first part of the night. In the dry-to-wet (MarchApril) and wet-to-dry (November-December) transition seasons, isolated rains induced rapid changes of soil moisture and vegetation activity, and thus rapid changes in the energy partitioning. These periods with high time-variability of surface properties are very useful in evaluating the ability of standard models to reproduce the dynamic of energy flux partitioning.

We showed that the Sakaguchi and Zeng (2009) soil resistance model fit the soil evaporation data well during the dry and dry-to-wet seasons, and that the Ball-Berry stomata conductance model accurately simulated the transpiration during the wet season. The limiting effect of surface temperature on transpiration above $30^{\circ} \mathrm{C}$ detected in the observations was also well reproduced by the Ball-Berry model. The study evidenced the large seasonal and daily amplitude of the skin surface temperature, and the role it plays in all the surface processes by (1) increasing the long wave radiation and thus limiting the net radiation during the dry season; (2) increasing ground heat fluxes and energy storage, and thus limiting transpiration during the wet season; (3) controlling $\mathrm{C} 4$ vegetation transpiration. As a consequence, specific attention has to be paid to the representation of surface temperature in 
land surface models to ensure a correct simulation of surface energy fluxes.

The quality of this data set makes it attractive for further research, including local evaluation of surface fluxes in land surface or atmospheric models. Further studies in this region should focus on other land cover types, such as forest areas. A comprehensive understanding of the processes driving the energy cycle for contrasting vegetation covers would allow for a better understanding and simulation of the impacts of land cover changes on the exchanges of energy at the surface-atmosphere interface in western Africa.

Acknowledgements. The AMMA-CATCH observing system (http://www.amma-catch.org/) has been funded since 2001 by IRD, INSU and the French Ministry of Research, in cooperation with the "Direction Générale de l'Eau (DG-Eau)", Benin. The Nalohou flux station was supported by the Ouémé-2025 project (French FSP-RIPIECSA program). The article processing charges have been funded by INSU-CNRS. The authors wish to particularly thank the researchers and technicians who helped them during the different steps of this work - G. Quantin, R. Biron, and M. Le Gall - and the Beninese technicians T. Ouani, S. Afouda, M. Wubda, S. Alloganvinon, and J. Sogba-Goh for their permanent support in the field. This work was made possible by the financial support provided by the IRD-DSF, the AUF-Bureau de l'Afrique de l'Ouest, and the Université d'Abomey-Calavi (Bénin).

Edited by: Y. Fan

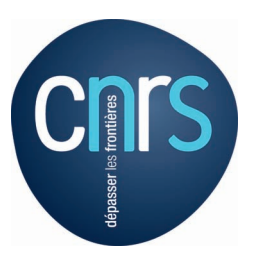

The publication of this article is financed by CNRS-INSU.

\section{References}

Aluwihare, S. and Watanabe, K.: Measurement of evaporation on bare soil and estimating surface resistance, J. Environ. Eng., 129, 1157-1168, 2003.

Aubinet, M., Grelle, A., Ibrom, A., Rannik, Ü, Moncrieff, J., Foken, T., Kowalski, A. S., Martin, P. H., Berbigier, P., Bernhofer, C., Clement, R., Elbers, J., Granier, A., Grünwald, T., Morgenstern, K., Pilegaard, K., Rebmann, C., Snijders, W., Valentini, R., and Vesala, T.: Estimates of the annual net carbon and water exchange of forests: the EUROFLUX methodology, Adv. Eco. Res., 30, 113-175, 1999.

Bagayoko, F., Yonkeu, S., Elbers, J., and van de Giesen, N.: Energy partitioning over the West African savanna: Multi-year evaporation and surface conductance measurements in Eastern Burkina Faso, J. Hydrol., 334, 545-559, 2007.
Boone, A., Decharme, B., Guichard, F., de Rosnay, P., Balsamo, G., Beljaars, A., Chopin, F., Orgeval, T., Polcher, J., Delire, C., Ducharne, A., Gascoin, S., Grippa, M., Jarlan, L., Kergoat, L., Mougin, E., Gusev, Y., Nasonova, O., Harris, P., Taylor, C., Norgaard, A., Sandholt, I., Ottlé, C., Poccard-Leclercq, I., SauxPicart, S., and Xue, Y.: The AMMA Land Surface Model Intercomparison Project (ALMIP), B. Am. Meteorol. Soc., 90, 18651880, 2009a.

Brümmer, C., Falk, U., Papen, H., Szarzynski, J., Wassmann, R., and Brüggemann, N.: Diurnal, seasonal, and interannual variation in carbon dioxide and energy exchange in shrub savanna in Burkina Faso (West Africa), J. Geophys. Res., 113, G02030, doi:10.1029/2007JG000583, 2008.

Businger, J. A., Wyngaard, J. C., Izumi, Y., and Bradley, E. F.: FluxProfile Relationships in the Atmospheric Surface Layer, J. Atmos. Sci., 28, 181-189, 1971.

Caird, M. A., Richards, J. H., and Donovan, L. A.: Nighttime Stomatal Conductance and Transpiration in C3 and C4 Plants, Plant Physiol., 143, 4-10, doi:10.1104/pp.106.092940, 2007.

Charney, J. G.: Dynamics of deserts and drought in the Sahel, Q. J. Roy. Meteorol. Soc., 101, 193-202, 1975.

Collatz, G. J., Ribas-Carbo, M., and Berry, J. A.: Coupled photosynthesis-stomatal conductance model for leaves of $\mathrm{C} 4$ plants, Funct. Plant Biol., 19, 519-538, 1992.

CSAO: Compte rendu du forum du club du sahel et de l'Afrique de l'Ouest, Peuplement, marché et sécurité alimentaire, Ouagadougou, 4-8 décembre 2012, 1-16, available from http://www.oecd.org/fr/csao/publications/FR-Compte\% 20rendu\%20forum.pdf (last access: 19 June 2013), 2012.

Culf, A. D., Foken, T., and Gash, J. H. C.: The energy balance closure problem, in: Vegetation, water, humans and the climate, A new perspective on an interactive system, edited by: Kabat, P. et al., Springer, Berlin, Heidelberg, 159-166, 2004.

De Condappa, D., Galle, S., Dewandel, B., and Haverkamp, R.: Bimodal zone of the soil textural triangle: Common in tropical and subtropical regions, Soil Sci. Soc. Am. J., 72, 33-40, 2008.

Descloitres, M., Séguis, L., Legchenko, A., Wubda, M., Guyot, A., and Cohard, J. M.: The contribution of MRS and resistivity methods to the interpretation of actual evapo-transpiration measurements: a case study in metamorphic context in north Benin, Near Surf. Geophys., 9, 187-200, 2011.

Detto, M., Montaldo, N., Albertson, J. D., Mancini, M. and Katul, G.: Soil moisture and vegetation controls on evapotranspiration in a heterogeneous Mediterranean ecosystem on Sardinia, Italy, Water Resour. Res., 42, W08419, doi:10.1029/2005WR004693, 2006.

Doukouré, M.: Variabilité des flux turbulents de surface au sein du bassin versant d'Ara au Bénin, Thèse de doctorat, Université de Grenoble, Grenoble, 171 pp., 2011.

Douville, H., Conil, S., Tyteca, S., and Voldoire, A.: Soil moisture memory and West African monsoon predictability: artefact or reality?, Clim. Dynam., 28, 723-742, doi:10.1007/s00382-0060207-8, 2006.

Eltahir, E. A.: A soil moisture-rainfall feedback mechanism 1. Theory and observations, Water Resour. Res., 34, 765-776, 1998.

Faure, P. and Volkoff, B.: Some factors affecting regional differentiation of the soils in the Republic of Benin (West Africa), Catena, 32, 281-306, 1998. 
Gentine, P., Entekhabi, D., Chehbouni, A., Boulet, G., and Duchemin, B.: Analysis of evaporative fraction diurnal behaviour, Agr. Forest. Meteorol., 143, 13-29, 2007.

Gentine, P., Entekhabi, D., and Polcher, J.: The Diurnal Behavior of Evaporative Fraction in the Soil-Vegetation-Atmospheric Boundary Layer Continuum, J. Hydrometeorol., 12, 1530-1546, 2012.

Guyot, A., Cohard, J.-M., Anquetin, S., Galle, S., and Lloyd, C. R.: Combined analysis of energy and water balances to estimate latent heat flux of a Sudanian small catchment, J. Hydrol., 375, 227-240, 2009.

Guyot, A., Cohard, J.-M., Anquetin, S., and Galle, S.: Long-term observations of turbulent fluxes over heterogeneous vegetation using scintillometry and additional observations: A contribution to AMMA under Sudano-Sahelian climate, Agr. Forest. Meteorol., 154-155, 84-98, 2012.

Horst, T. W. and Weil, Jc.: Footprint estimation for scalar flux measurements in the atmospheric surface layer, Bound.-Lay. Meteorol., 59, 279-296, 1992.

Hsieh, C.-I., Katul, G., and Chi, T.: An approximate analytical model for footprint estimation of scalar fluxes in thermally stratified atmospheric flows, Adv. Water Res., 23, 765-772, 2000.

Hsieh, C.-I., Katul, G. G., Schieldge, J., Sigmon, J. T., and Knoerr, K. K.: The Lagrangian Stochastic Model for fetch and latent heat flux estimation above uniform and nouniform terrain, Water Resour. Res., 33, 427-438, 1997.

Inagaki, A., Letzel, M. O., Raasch, S., and Kanda, M.: Impact of surface heterogeneity on energy balance: A study using LES, J. Meteorol. Soc. Jpn., 84, 187-198, 2006.

Jarvis, P. G. and McNaughton, K. G.: Stomatal control of transpiration: scaling up from leaf to region, Adv. Eco. Res., 15, 1-49, 1986.

Judex, M., Thamm, H.-P., Röhrig, J., and Schulz, O.: IMPETUS Atlas du Bénin Résultats de recherche 2000-2007, Département de Géographie, Université de Bonn, Allemagne, 2009.

Kabat, P., Dolman, A. J., and Elbers, J. A.: Evaporation, sensible heat and canopy conductance of fallow savannah and patterned woodland in the Sahel, J. Hydrol., 188, 494-515, 1997.

Kaimal, J. C. and Finnigan, J. J.: Atmospheric boundary layer flows: their structure and measurement, Oxford University Press., 1994.

Kanda, M., Inagaki, A., Letzel, M. O., Raasch, S., and Watanabe, T.: LES study of the energy imbalance problem with eddy covariance fluxes, Bound.-Lay. Meteorol., 110, 381-404, 2004.

Kljun, N., Calanca, P., Rotach, M. W., and Schmid, H. P.: A Simple Parameterisation for Flux Footprint Predictions, Bound.-Lay. Meteorol., 112, 503-523, 2004.

Koster, R. D., Dirmeyer, P. A., Guo, Z., Bonan, G., Chan, E., Cox, P., Gordon, C. T., Kanae, S., Kowalczyk, E., Lawrence, D., Liu, P., Lu, C.-H., Malyshev, S., McAvaney, B., Mitchell, K., Mocko, D., Oki, T., Oleson, K., Pitman, A., Sud, Y. C., Taylor, C. M., Verseghy, D., Vasic, R., Xue, Y., and Yamada, T. (The GLACE Team): Regions of Strong Coupling Between Soil Moisture and Precipitation, Science, 305, 1138-1140, 2004.

Kounouhéwa, B., Mamadou, O., Koto N'gobi, G., and Awanou, C. N.: Dynamics and Diurnal Variations of Surface Radiation Budget over Agricultural Crops Located in Sudanian Climate, Atmos. Clim. Sci., 03, 121-131, doi:10.4236/acs.2013.31014, 2013.
Lebel, T., Parker, D. J., Flamant, C., Bourlès, B., Marticorena, B., Mougin, E., Peugeot, C., Diedhiou, A., Haywood, J. M., Ngamini, J. B., Polcher, J., Redelsperger, J.-L., and Thorncroft, C. D.: The AMMA field campaigns: multiscale and multidisciplinary observations in the West African region, Q. J. Roy. Meteorol. Soc., 136, 8-33, 2009.

Lee, T. J. and Pielke, R. A.: Estimating the Soil Surface Specific Humidity, J. Appl. Meteorol., 31, 480-484, 1992.

Lelay, M. and Galle, S.: How changing rainfall regimes may affect the water balance: a modelling approach in West Africa, in: Regional Hydrological Impacts of Climatic Change: Hydroclimatic variability, edited by: Franks, S., Wagener, T., Bogh, E., Gupta, H. V., Bastidas, L., Nobre, C., and De Oliveira Galvao, C., AISH Publication 296, 203-210, 2005.

Lohou, F., Saïd, F., Lothon, M., Durand, P., and Serça, D.: Impact of Boundary-Layer Processes on Near-Surface Turbulence Within the West African Monsoon, Bound.-Lay. Meteorol., 136, 1-23, 2010.

Lohou, F., Kergoat, L., Guichard, F., Boone, A., Cappelaere, B., Cohard, J.-M., Demarty, J., Galle, S., Grippa, M., Peugeot, C., Ramier, D., Taylor, C. M., and Timouk, F.: Surface response to rain events throughout the West African monsoon, Atmos. Chem. Phys. Discuss., 13, 18581-18620, doi:10.5194/acpd-13-185812013, 2013.

Lothon, M., Saïd, F., Lohou, F., and Campistron, B.: Observation of the Diurnal Cycle in the Low Troposphere of West Africa, Mon. Weather Rev., 136, 3477-3500, 2008.

Mauder, M. and Foken, T.: Documentation and instruction manual of the eddy covariance software package TK2, Univ., Abt. Mikrometeorologie Bayreuth, Bayreuth, 2004.

Mauder, M., Jegede, O. O., Okogbue, E. C., Wimmer, F., and Foken, T.: Surface energy balance measurements at a tropical site in West Africa during the transition from dry to wet season, Theor. Appl. Climatol., 89, 171-183, 2007.

Monteny, B. A., Lhomme, J. P., Chehbouni, A., Troufleau, D., Amadou, M., Sicot, M., Verhoef, A., Galle, S., Said, F., and Lloyd, C. R.: The role of the Sahelian biosphere on the water and the $\mathrm{CO}_{2}$ cycle during the HAPEX-Sahel experiment, J. Hydrol., 188-189, 516-535, doi:10.1016/S0022-1694(96)03191-5, 1997.

Monteny, B. A., Lhomme, J. P., Chehbouni, A., Troufleau, D., Amadou, M., Sicot, M., Verhoef, A., Galle, S., Said, F., and Lloyd, C. R.: The role of the Sahelian biosphere on the water and the $\mathrm{CO}_{2}$ cycle during the HAPEX-Sahel experiment, J. Hydrol., 188-189, 516-535, doi:10.1016/S0022-1694(96)03191-5, 2007.

Moore, C. J.: Frequency response corrections for eddy correlation systems, Bound.-Lay. Meteorol., 37, 17-35, 1986.

Parker, D. J., Burton, R. R., Diongue-Niang, A., Ellis, R. J., Felton, M., Taylor, C. M., Thorncroft, C. D., Bessemoulin, P., and Tompkins, A. M.: The diurnal cycle of the West African monsoon circulation, Q. J. Roy. Meteorol. Soc., 131, 2839-2860, 2005.

Philippon, N. and Fontaine, B.: The relationship between the Sahelian and previous 2nd Guinean rainy seasons: a monsoon regulation by soil wetness?, Ann. Geophys., 20, 575-582, doi:10.5194/angeo-20-575-2002, 2002. 
Pospichal, B., Karam, D., Crewell, S., Flamant, C., Hünerbein, A., Bock, O., and Saïd, F.: Diurnal cycle of the intertropical discontinuity over West Africa analysed by remote sensing and mesoscale modelling, Q. J. Roy. Meteorol. Soc., 136, 92-106, 2010.

Ramier, D., Boulain, N., Cappelaere, B., Timouk, F., Rabanit, M., Lloyd, C. R., Boubkraoui, S., Métayer, F., Descroix, L., and Wawrzyniak, V.: Towards an understanding of coupled physical and biological processes in the cultivated Sahel -1 . Energy and water, J. Hydrol., 375, 204-216, 2009.

Redelsperger, J.-L., Thorncroft, C. D., Diedhiou, A., Lebel, T., Parker, D. J., and Polcher, J.: African Monsoon Multidisciplinary Analysis: An International Research Project and Field Campaign, B. Am. Meteorol. Soc., 87, 1739-1746, doi:10.1175/BAMS-87-12-1739, 2006.

Richard, A., Galle, S., Descloitres, M., Cohard, J.-M., Vandervaere, J.-P., Séguis, L., and Peugeot, C.: Interplay of riparian forest and groundwater in the hillslope hydrology of Sudanian West Africa (northern Benin), Hydrol. Earth Syst. Sci., 17, 50795096, doi:10.5194/hess-17-5079-2013, 2013.

Sakaguchi, K. and Zeng, X.: Effects of soil wetness, plant litter, and under-canopy atmospheric stability on ground evaporation in the Community Land Model (CLM3.5), J. Geophys. Res., 114, D01107, doi:10.1029/2008JD010834, 2009.

Santanello, J. A. and Friedl, M. A.: Diurnal Covariation in Soil Heat Flux and Net Radiation, J. Appl. Meteorol., 42, 851-862, 2003.

Schmid, H. P.: Footprint modeling for vegetation atmosphere exchange studies: a review and perspective, Agric. Forest. Meteorol., 113, 159-183, 2002.

Schotanus, P., Nieuwstadt, F. T. M., and De Bruin, H. A. R.: Temperature measurement with a sonic anemometer and its application to heat and moisture fluxes, Bound.-Lay. Meteorol., 26, 81-93, 1983.

Schüttemeyer, D., Moene, A. F., Holtslag, A. A. M., Bruin, H. A. R., and van Giesen, N.: Surface Fluxes and Characteristics of Drying Semi-Arid Terrain in West Africa, Bound.-Lay. Meteorol., 118, 583-612, 2006.

Seghieri, J., Vescovo, A., Padel, K., Soubie, R., Arjounin, M., Boulain, N., de Rosnay, P., Galle, S., Gosset, M., Mouctar, A. H., Peugeot, C., and Timouk, F.: Relationships between climate, soil moisture and phenology of the woody cover in two sites located along the West African latitudinal gradient, J. Hydrol., 375, 78-89, 2009.

Séguis, L., Kamagaté, B., Favreau, G., Descloitres, M., Seidel, J.-L., Galle, S., Peugeot, C., Gosset, M., Le Barbé, L., Malinur, F., Van Exter, S., Arjounin, M., Boubkraoui, S., and Wubda, M.: Origins of streamflow in a crystalline basement catchment in a subhumid Sudanian zone: The Donga basin (Benin, West Africa): Inter-annual variability of water budget, J. Hydrol., 402, 1-13, 2011.

Sellers, P. J., Heiser, M. D., and Hall, F. G.: Relations between surface conductance and spectral vegetation indices at intermediate $\left(100 \mathrm{~m}^{2}\right.$ to $\left.15 \mathrm{~km}^{2}\right)$ length scales, J. Geophys. Res., $97,19033-$ 19059, 1992.

Snyder, K. A., Richards, J. H., and Donovan, L. A.: Night-time conductance in $\mathrm{C} 3$ and $\mathrm{C} 4$ species: do plants lose water at night?, J. Exp. Bot., 54, 861-865, doi:10.1093/jxb/erg082, 2003.
Steinfeld, G., Letzel, M. O., Raasch, S., Kanda, M., and Inagaki, A.: Spatial representativeness of single tower measurements and the imbalance problem with eddy-covariance fluxes: Results of a large-eddy simulation study, Bound.-Lay. Meteorol., 123, 77-98, 2007.

Sultan, B. and Janicot, S.: The West African monsoon dynamics, Part II: The "preonset" and "onset" of the summer monsoon, J. Climate, 16, 3407-3427, 2003.

Taylor, C. M. and Lebel, T.: Observational evidence of persistent convective-scale rainfall patterns, Mon. Weather Rev., 126, 1597-1607, 1998.

Taylor, C. M., de Jeu, R. A. M., Guichard, F., Harris, P. P., and Dorigo, W. A.: Afternoon rain more likely over drier soils, Nature, 489, 423-426, 2012.

Thornton, E.: Technical Description of version 4.0 of the Community Land Model (CLM), available from: http://nldr.library.ucar. edu/repository/assets/technotes/asset-000-000-000-847.pdf (last access: 29 May 2013), 2010.

Timouk, F., Kergoat, L., Mougin, E., Lloyd, C. R., Ceschia, E., Cohard, J. M., Rosnay, P., Hiernaux, P., Demarez, V., and Taylor, C. M.: Response of surface energy balance to water regime and vegetation development in a Sahelian landscape, J. Hydrol., 375, 178-189, 2009.

UN - United Nations, Department of Economic and Social Affairs, Population Division, World Population Prospects: The 2010 Revision, Press Release (3 May 2011): World Population to reach 10 billion by 2100 if fertility in all countries converges to replacement Level, available on: http://esa.un.org/ unpd/wpp/other-information/press_releasewpp2010.pdf (last access: 19 June 2013), 2011.

van de Griend, A. A. and Owe, M.: Bare soil surface resistance to evaporation by vapor diffusion under semiarid conditions, Water Resour. Res., 30, 181-188, 1994.

Webb, E. K., Pearman, G. I., and Leuning, R.: Correction of flux measurements for density effects due to heat and water vapour transfer, Q. J. Roy. Meteorol. Soc., 106, 85-100, 1980.

Weiss, M., Baret, F., Smith, G. J., Jonckheere, I., and Coppin, P.: Review of methods for in situ leaf area index (LAI) determination: Part II, Estimation of LAI, errors and sampling, Agr. For. Meteorol., 121, 37-53, 2004.

Wilson, K., Goldstein, A., Falge, E., Aubinet, M., Baldocchi, D., Berbigier, P., Bernhofer, C., Ceulemans, R., Dolman, H., Field, C., Grelle, A., Ibrom, A., Law, B. E., Kowalski, A., Meyers, T., Moncrieff, J., Monson, R., Oechel, W., Tenhunen, J., Valentini, R., and Verma, S. : Energy balance closure at FLUXNET sites, Agr. Forest. Meteorol., 113, 223-243, 2002.

Xue, Y. and Shukla, J.: The influence of land surface properties on Sahel climate, Part I: Desertification, J. Climate, 6, 2232-2245, 1993.

Zeng, N., Neelin, J. D., Lau, K.-M., and Tucker, C. J.: Enhancement of Interdecadal Climate Variability in the Sahel by Vegetation Interaction, Science, 286, 1537-1540, 1999. 